\title{
The Proline/Arginine Dipeptide from Hexanucleotide Repeat Expanded C9ORF72 Inhibits the Proteasome
}

\author{
(1) Rahul Gupta, ${ }^{1,2, *}$ Matthews Lan,, ${ }^{3, *}$ Jelena Mojsilovic-Petrovic, ${ }^{4}$ Won Hoon Choi, ${ }^{5}$ Nathaniel Safren, ${ }^{6}$ \\ Sami Barmada, ${ }^{6}$ - Min Jae Lee, ${ }^{5}$ and Robert Kalb ${ }^{4,7}$
}

\section{DOI:http://dx.doi.org/10.1523/ENEURO.0249-16.2017}

\begin{abstract}
${ }^{1}$ Department of Chemical and Biomolecular Engineering, School of Engineering and Applied Sciences, University of Pennsylvania, Philadelphia, PA, 19104, ${ }^{2}$ Department of Biology, College of Arts and Sciences, University of Pennsylvania, Philadelphia, PA, 19104, ${ }^{3}$ Department of Biochemistry, College of Arts and Sciences, University of Pennsylvania, Philadelphia, PA, 19104, ${ }^{4}$ Division of Neurology, Department of Pediatrics, Research Institute, Children's Hospital of Philadelphia, Philadelphia, PA, 19104, ${ }^{5}$ Department of Biochemistry and Molecular Biology, Seoul National University College of Medicine, Seoul 03080, Republic of Korea, ${ }^{6}$ Department of Neurology, University of Michigan, Ann Arbor, MI, 48109, and ${ }^{7}$ Department of Neurology, Perelman School of Medicine, University of Pennsylvania, Philadelphia, PA, 19104
\end{abstract}

\begin{abstract}
An intronic hexanucleotide repeat expansion (HRE) mutation in the C9ORF72 gene is the most common cause of familial ALS and frontotemporal dementia (FTD) and is found in $\sim 7 \%$ of individuals with apparently sporadic disease. Several different diamino acid peptides can be generated from the HRE by noncanonical translation (repeat-associated non-ATG translation, or RAN translation), and some of these peptides can be toxic. Here, we studied the effects of two arginine containing RAN translation products [proline/arginine repeated 20 times $\left(\mathrm{PR}_{20}\right)$ and glycine/arginine repeated 20 times $\left(\mathrm{GR}_{20}\right)$ ] in primary rat spinal cord neuron cultures grown on an astrocyte feeder layer. We find that $\mathrm{PR}_{20}$ kills motor neurons with an $\mathrm{LD}_{50}$ of $2 \mu \mathrm{M}$, but in contrast to the effects of other ALS-causing mutant proteins (i.e., SOD or TDP43), $\mathrm{PR}_{20}$ does not evoke the biochemical signature of mitochondrial dysfunction, ER stress, or mTORC down-regulation. $\mathrm{PR}_{20}$ does result in a time-dependent build-up of ubiquitylated substrates, and this is associated with a reduction of flux through both autophagic and proteasomal degradation pathways. $\mathrm{GR}_{20}$, however, does not have these effects. The effects of $\mathrm{PR}_{20}$ on the proteasome are likely to be direct because (1) $\mathrm{PR}_{20}$ physically associates with proteasomes in biochemical assays, and (2) $\mathrm{PR}_{20}$ inhibits the degradation of a ubiquitylated test substrate when presented to purified proteasomes. Application of a proteasomal activator (IU1) blocks the toxic effects of $\mathrm{PR}_{20}$ on motor neuron survival. This work suggests that proteasomal activators have therapeutic potential in individuals with C9ORF72 HRE.
\end{abstract}

Key words: ALS; frontotemporal dementia; lysosome-autophagy; motor neuron; proteasome

\section{Significance Statement}

Peptides made up of two alternating amino acids, proline/arginine (PR) or glycine/arginine (GR), are thought to contribute to the pathophysiology of familial ALS and frontotemporal dementia (FTD) caused by expansion of the intronic microsatellite repeat sequence GGGGCC in the C9ORF72 gene. Here, we show that proline/arginine repeated 20 times $\left(\mathrm{PR}_{20}\right)$ is toxic to motor neurons and inhibits substrate flux through the proteasome and the lysosomal-autophagy pathway. Stimulation of the proteasome alleviates this toxicity, suggesting that targeting the $\mathrm{PR}_{20}$-proteasome interaction may have therapeutic potential. 


\section{Introduction}

ALS is an adult-onset, fatal neurodegenerative disease that manifests with progressive weakness, muscle wasting, spasticity, and respiratory failure (Wijesekera and Leigh, 2009), signs and symptoms that result from the death of upper and lower motor neurons (Rowland and Shneider, 2001). Approximately 10\% of ALS cases are caused by single gene mutations; the remaining 90\% of cases are sporadic (Kiernan et al., 2011).

To date, the most common genetic abnormality underlying familial ALS is an expansion of the hexanucleotide sequence GGGGCC in the intron located between exons $1 \mathrm{a}$ and $1 \mathrm{~b}$ of the C9ORF72 gene (Renton et al., 2011; DeJesus-Hernandez et al., 2011). The majority of normal individuals have fewer than 8 GGGGCC repeats, whereas patients can have hexanucleotide repeat expansions (HREs) consisting of several hundreds or even thousands of repeats (Rutherford et al., 2012). Pre-mRNA transcripts containing the HRE adopt a G-quadruplex structure that can lead to sequestration of RNA-binding proteins and reduced abundance of the mature C9ORF72 mRNA (ConIon et al., 2016; Lee et al., 2016; Lin et al., 2016). In some experimental platforms, the pathophysiology of C9ORF72 HRE can at least partially be linked to these mRNA structures (Haeusler et al., 2014).

Additionally, the pre-mRNA produced from the HRE undergoes translation despite the lack of the ATG start codon. This repeat-associated non-ATG (RAN) translation results in the production of 5 different dipeptide repeat (DPR) proteins, depending on the reading frame and on the translation of the sense or antisense strand. The arginine-rich RAN translation products $P R_{n}$ and $G R_{n}$ as well as $\mathrm{GA}_{n}$ (where the $n$ represents the number of dipeptide repeats) have been shown to result in neurodegeneration (Mizielinska et al., 2014; Zhang et al., 2014). Recent work establishes that DPRs can undergo cell-tocell transfer (Westergard et al., 2016).

Received August 19, 2016; accepted January 12, 2017; First published January 24, 2017.

The authors declare no competing financial interests.

Author contributions: R.G., R.K., and M.L. designed research; R.K., W.H.C., N.S., S.B., and M.J.L., performed research; R.G., M.L., J. M.-P., and N.S., contributed unpublished reagents/analytic tools; R.K. analyzed data; R.G., M.L., W.H.C., N.S., S.B., M.J.L, and R.K. wrote the paper.

This work is supported by National Institutes of Health Grants NS087077 and NS052325 (to R.G.K.) and NS072233 and R01-NS097542 (to S.B.), the National Research Foundation of Korea Grant 2016R1A2B2006507 and the Brain Research Program Grant 2016M3C7A1913895 (to M.J.L.), and the Roy \& Diana Vagelos Scholars Program in the Molecular Life Sciences (M.L.).

${ }^{*}$ R.G. and M.L. are co-first authors.

Acknowledgements: We thank the generosity of Steve McKnight (University of Texas, Southwestern) for sharing synthetic peptides for initial studies and Daniel Finley (Harvard Medical School) for thoughtful discussions.

Correspondence should be addressed to either of the following: Robert Kalb at the above address, E-mail: kalb@email.chop.edu; or Min Jae Lee at the above address, E-mail: minjlee@snu.ac.kr.

DOI:http://dx.doi.org/10.1523/ENEURO.0249-16.2017

Copyright (C) 2017 Gupta et al.

This is an open-access article distributed under the terms of the Creative Commons Attribution 4.0 International, which permits unrestricted use, distribution and reproduction in any medium provided that the original work is properly attributed.
The mechanism by which C9ORF72-associated RNA or DPR proteins impart toxicity onto cells is under active investigation. Although recent work points to defects in nucleocytoplasmic shuttling in C9ORF72 HRE pathophysiology (Freibaum et al., 2015; Joviči et al., 2015; Zhang et al., 2015; Boeynaems et al., 2016), many questions remain. First, is HRE-mediated toxicity due to the HRE mRNA, DPR proteins, or both? Although several groups that have found defects in nucleocytoplasmic transport in the setting of C9ORF72 HRE, they come to opposite conclusions regarding the toxic agent (Joviči et al., 2015; Freibaum et al., 2015; Zhang et al., 2015). Considering the differences in molecular structure between the HRE mRNA/DNA and DPR proteins, a priori, it seems unlikely that both would affect similar structures in the nuclear pore complex. Second, by what mechanism are impairments in nucleocytoplasmic shuttling injurious to cells and why are select neuronal populations affected? Essentially no information is extant on these issues. A system that unambiguously dissociates RNA from DPR protein toxicity could begin to provide insight into these pressing questions.

Here, we explore DPR protein toxicity by interrogating primary spinal cord neuronal cultures grown on an astrocyte feeder layer treated with synthetically produced proline/arginine repeated 20 times $\left(\mathrm{PR}_{20}\right)$ or glycine/arginine repeated 20 times $\left(\mathrm{GR}_{20}\right)$, obviating the distinction between DPR protein and mRNA-mediated toxicity. Unexpectedly, perturbed cellular processes previously implicated in genetic models of ALS (Kong and Xu, 1998; Betz and Hall, 2013; Saxena et al., 2013; Perera et al., 2014), such as mitochondrial dysfunction, ER stress, and mTOR down-regulation, were unaffected by $\mathrm{PR}_{20}$ in this model. Instead, we find that $\mathrm{PR}_{20}$ (but not $\mathrm{GR}_{20}$ ) disrupts the activity of the ubiquitin-proteasome system (UPS) and the autophagy pathway. In addition, $\mathrm{PR}_{20}$ (but not $\mathrm{GR}_{20}$ ) associates with and directly inhibits proteasomes in vitro. We show that stimulating UPS activity protects against $\mathrm{PR}_{20}$-mediated motor neuron death. The implication of the cellular protein degradation pathway in $\mathrm{PR}_{20}$ toxicity suggests that the build-up of cellular proteins that are marked for degradation through ubiquitylation may result in RAN peptidemediated C9ORF72 HRE toxicity.

\section{Materials and Methods}

\section{Antibodies}

The following antibodies were used in this study: ubiquitin (Dako Z0458), phospho-P70 S6K (Cell Signaling, T389), P70 S6K (Cell Signaling, 9202S), phospho-4EBP1 (Cell Signaling, 2855S), 4EBP1 (Cell Signaling, 9452), phospho-AMPK (Cell Signaling, 2535S), AMPK (Cell Signaling, 2532S), HA (Roche, 3F10), $\alpha 3$ (Enzo Life Sciences, MCP257), T7 (EMD Millipore, 69522) $\beta$-actin (Sigma A2066), anti-mouse and anti-rabbit Alexa Fluor 488 and 594 antibodies (Invitrogen), and anti-mouse and antirabbit IRDye antibodies (Li-Cor).

\section{Culture generation}

Mixed spinal cord neuron cultures were prepared as described previously (Mojsilovic-Petrovic et al., 2006). 
Briefly, an astrocyte feeder layer was prepared from the cortex of newborn Sprague Dawley rat pups [postnatal day 2 (P2)] and grown to $\sim 80 \%$ confluency. Subsequently, dissociated embryonic day 15 (E15) spinal cord neurons were added. One to two days later, AraC (5 mM) (catalog \#C6645; Sigma) was added for $24 \mathrm{~h}$ to arrest astrocyte proliferation. Cultures were maintained in gliaconditioned medium supplemented with the following trophic factors $(1.0 \mathrm{ng} / \mathrm{ml}$ each): human neurotrophin-3, human neurotrophin-4, human brain-derived neurotrophic factor, and rat ciliary neurotrophic factor (Alomone Labs). Half of the culture medium was replaced on a biweekly basis.

\section{Toxicity assays and $\mathrm{LD}_{50}$ determination of $\mathrm{PR}_{\mathbf{2 0}}$ or MG132}

Days in vitro (DIV)14 mixed spinal cord cultures were exposed to $\mathrm{PR}_{20}$ or $\mathrm{GR}_{20}$ by addition of synthetic peptide to the media one time. Cultures were fixed $5 \mathrm{~d}$ later with freshly prepared $4 \%$ paraformaldehyde for $20 \mathrm{~min}$, washed extensively with $0.1 \mathrm{M} \mathrm{PBS}, \mathrm{pH} 7.4$, and immunostained with SMI32 to identify motor neurons. Immunopositive cells $>25 \mu \mathrm{m}$ in diameter are motor neurons based on their costaining for peripherin, ChAT, and islet 1/2 (Mojsilovic-Petrovic et al., 2006). Motor neurons were counted in three nonoverlapping, randomly selected fields on a coverslip using a 5[times objective, and the values from a single coverslip averaged. The results of 3-5 independently treated coverslips were the basis and means and variance used in statistical analysis. Each experiment was repeated with independently generated culture $4+$ times (Mojsilovic-Petrovic et al., 2006).

To determine the $\mathrm{LD}_{50}$ of DPR peptides, $\mathrm{PR}_{20}$ or $\mathrm{GR}_{20}$ was added once to the culture media of DIV14 cultures such that the final concentration varied from $2 \mathrm{nM}$ to 35 $\mu \mathrm{M}$ at approximately 10 -fold increments. Motor neuron survival $5 \mathrm{~d}$ later was determined. Once the approximate $\mathrm{LD}_{50}$ was determined, we repeated the analysis with more closely spaced concentrations for a more precise definition of the $\mathrm{LD}_{50}$. Determination of the $\mathrm{LD}_{50}$ of MG132 was accomplished in an identical manner.

For experiments involving IU1, DIV14 cultures were treated with $\mathrm{PR}_{20}$ or its vehicle, and every other day, IU1 (or vehicle) was added to the culture media to achieve a final concentration of $5 \mu \mathrm{M}$. At DIV19, cultures were fixed and motor neuron number determined as described above.

For experiments involving astrocytes only, freshly dissociated astrocytes were plated in 96-well dishes and maintained as above. Near confluent cultures were then exposed to various concentrations of $\mathrm{PR}_{20}$ or $\mathrm{GR}_{20}$ for $5 \mathrm{~d}$ and the XTT Cell Viability assay (Thermo Fisher Scientific, catalog \#X6493) was performed per manufacturers guidelines. Absorbance at $450 \mathrm{nM}$ was obtained using a BIOTEK Synergy HT plate reader. This experiment was performed in triplicate.

\section{$\mathrm{PR}_{20}$ treatment for biochemical assays}

Confluent dishes of astrocyte neuron cocultures at $37^{\circ} \mathrm{C}$ had volumes equalized to $2 \mathrm{ml}$ of cell culture media each. Approximately $300 \mu \mathrm{l}$ of media from each dish was removed and pooled with other dishes, $\mathrm{PR}_{20}$ stock solution was added, and the mixture was then added back to the corresponding culture dish, so that each dish contained a final concentration of $2 \mu \mathrm{M}$. All plates were incubated with $\mathrm{PR}_{20}$ for $48 \mathrm{~h}$.

\section{Ubiquitylation assay}

The ubiquitylation assay involved acute time point treatments with $\mathrm{PR}_{20} .16 \mathrm{~h}$ prior to scheduled lysis, two dishes were treated to a final concentration of $2 \mu \mathrm{M} \mathrm{PR}_{20}$ using the methods described in the $\mathrm{PR}_{20}$ treatment for biochemical assays subsection. This was repeated $8 \mathrm{~h}$ prior to lysis, $4 \mathrm{~h}$ prior to lysis, and $2 \mathrm{~h}$ prior to lysis. Samples were then lysed in RIPA buffer as described in Cell lysis for ubiquitin blots and processed for Western blot analysis.

\section{MG-132 flux assay}

MG-132 (Sigma) was used to inhibit proteasomal function. Cells were initially treated with $\mathrm{PR}_{20}$ for a total of 48 $h$ using the method outlined in $\mathrm{PR}_{20}$ treatment for biochemical assays. Four hours prior to lysis, these cells were treated with MG-132 or vehicle. The MG-132 was kept in a stock solution in DMSO. This was added directly to culture to achieve a final concentration of $5 \mu \mathrm{M}$. Cells were then lysed in RIPA buffer and immunoblotted for ubiquitin.

\section{Cell lysis}

Lysis buffer was prepared containing 1\% (v/v) protease inhibitor cocktail, $1 \%(\mathrm{v} / \mathrm{v})$ PMSF, and $1 \%(\mathrm{v} / \mathrm{v})$ leucine in $1 \%$ RIPA buffer solution on ice. Culture dishes were washed once with ice-cold PBS to remove any remaining media. A total of $125 \mu \mathrm{l}$ (35-mm dish), $150 \mu \mathrm{l}$ (6-well plate), or $250 \mu \mathrm{L}$ (60-mm dish) of lysis buffer was added to each plate, and cells were scraped into a cold $1.5-\mathrm{ml}$ tube. Samples were sonicated for $30 \mathrm{~s}$ at $20 \%$ intensity, placed on a rotator at $4^{\circ} \mathrm{C}$ for $20 \mathrm{~min}$, and then centrifuged for $15 \mathrm{~min}$ at 13,200 rpm. Supernatant was then removed from each tube for further analysis.

\section{Cell lysis for ubiquitin blots}

Ubiquitin analysis requires the use of deubiquitinase (DUB) inhibitors. Lysis without these inhibitors runs the risk of degradation of the substrates to be targeted. As such, $N$-ethylmaleimide (Sigma), a potent DUB inhibitor, was used in the lysis buffer. The lysis buffer was prepared containing $1 \%(\mathrm{v} / \mathrm{v})$ protease inhibitor cocktail, $1 \%(\mathrm{v} / \mathrm{v})$ PMSF, $1 \%(\mathrm{v} / \mathrm{v})$ leucine, and $50 \mu \mathrm{M}$ NEM in $1 \%$ RIPA buffer solution. The remainder of the lysis procedure follows Cell lysis.

\section{Membrane stripping}

Once scanning of the nitrocellulose membranes probed for 4EBP1/P-4EBP1 and S6K/P-S6K had been completed, Restore Western Blot Stripping Buffer (Thermo Fisher Scientific) was used to strip the blot of antibodies. The membranes were washed twice in PBS-T for $10 \mathrm{~min}$ each and then placed in the stripping buffer for $22 \mathrm{~min}$. The membranes were then washed twice once again in PBS-T for 10 min. They were then placed in blocking 
solution (5\% w/v milk in PBS-T) for $45 \mathrm{~min}$. This resulted in membranes with sample attached and no antibodies, ready to be probed for actin.

\section{In vitro Ub-Sic1 degradation assays}

Polyubiquitylated Sic1 proteins with PY degron motifs and $\mathrm{T} 7$ tag (Ub-Sic1) was prepared as previously described by Choi et al. (2016). Different concentrations of $\mathrm{PR}_{20}$ peptides $(0,50$, or $500 \mathrm{nM})$ and purified affinitypurified human proteasomes ( $5 \mathrm{nM}$ ) were preincubated 20 min in proteasome assay buffer [50 mM Tris- $\mathrm{HCl}(\mathrm{pH} 7.5)$, $100 \mathrm{mM} \mathrm{NaCl}, 10 \%$ glycerol, $2 \mathrm{mM} \mathrm{ATP,}, 10 \mathrm{mM} \mathrm{MgCl}$, and $1 \mathrm{mM}$ DTT] on ice, and $20 \mathrm{nM}$ reconstituted Ub-Sic1 was subsequently added. Degradation of Ub-Sic1 and $\mathrm{PR}_{20}$ peptides was monitored by immunoblotting using anti-T7 and anti-HA antibodies, respectively. Band intensities were quantified using ImageJ software (version $1.48 \mathrm{k}, \mathrm{NIH})$ from three independent immunoblotting assays $(n=3)$.

\section{Direct interaction between $\mathbf{P R}_{20}$ and human proteasomes}

Whole-cell extracts from a stable HEK293T cell line harboring $\mathrm{HTBH}$-tagged $\beta 4$ subunits were prepared as in Han et al. (2014) and incubated with HA-tagged $\mathrm{PR}_{20}$ or $\mathrm{GR}_{20}$ peptides $(2 \mu \mathrm{M}) 2 \mathrm{~h}$ at $4^{\circ} \mathrm{C}$. The resulting proteasome-dipeptide complexes were pull-downed with streptavidin agarose beads (Millipore) for $3 \mathrm{~h}$ at $4^{\circ} \mathrm{C}$. Unbound proteasomes in the supernatants were discarded, and the pellets were mixed with $2 \times$ SDS sample buffer. Different amounts of samples were resolved by SDS-PAGE/immunoblotting against HA and a proteasome core particle $\alpha 3$ subunit.

\section{Autophagic flux assay}

Primary spinal neurons were dissected from E15 rat pups and cultured at a density of $2.5 \times 10^{5} \mathrm{cells} / \mathrm{ml}$ on a laminin/poly-lysine-coated 96-well plate in motor neuron media. Four days after plating, neurons were transfected with Lipofectamine 2000 (Invitrogen). DNA-Lipofectamine mixtures were incubated with neurons for $20 \mathrm{~min}$ followed by rinsing. Neurons were then placed in $100 \mu \mathrm{L}$ of conditioned media that was collected immediately prior to transfection and half fresh motor neuron media containing $4 \mu \mathrm{M} \mathrm{PR}_{20}$, resulting in a final concentration of $2 \mu \mathrm{M} \mathrm{PR}_{20}$.

Optical pulse labeling experiments were performed using an automated microscopy platform previously described by Arrasate et al. (2004) and Barmada et al. (2014). A Nikon Eclipse Ti inverted microscope equipped with a PerfectFocus system, $20 \times$ objective lens and an Andor iXon3 897 EMCCD camera were used to acquire images. Samples were illuminated with a Sutter Instruments Lamba XL lamp. The microscope and related components were encased in custom-built plexiglass enclosure set to maintain the temperature at $37^{\circ} \mathrm{C}$ and $\mathrm{CO}_{2}$ at $5 \%$. Semrock GFP and TRITC filters were used for excitation and detection. A Semrock 405-nm long-pass filter was used for photoactivation. Image acquisition and stage movements were accomplished in an automated fashion using $\mu$ Manager and original code written in BeanShell. For all experiments, photoconversion occurred
$24 \mathrm{~h}$ following transfection. GFP and TRITC images were acquired immediately following activation and subsequently every $2 \mathrm{~h}$ for $12 \mathrm{~h}$. Images were acquired in a similar 12-h window starting $48 \mathrm{~h}$ after $\mathrm{PR}_{20}$ treatment. Using in-house image analysis scripts, neuronal cell bodies were identified based on their fluorescent intensity and morphology, and a ROI was drawn around the perimeter of each cell at each time. Single-cell TRITC intensity values were recorded and used to fit a first order exponential decay curve for individual neurons and calculate a Dendra2-light chain 3 (LC3) half-life for each cell.

\section{Statistical analysis}

To determine whether IU1 treatment had an effect on cell survival, a one tailed, one sample Student's $t$ test was used to test the hypothesis that IU1 would improve cell survival when used with $\mathrm{PR}_{20}$.

To test for group differences in the flux assay, a permutation test was used. This is a nonparametric statistical test that was implemented in MATLAB. The goal of the test was to determine whether the +MG132/-MG132 ratio changed significantly in the presence of $P R_{20}$. The test first quantifies this by taking the average of each experimental group and then finding the difference of ratios. It then permutes two samples located in two groups randomly, and determines that difference between averages again. This is repeated 50,000 times, and a histogram is plotted. This histogram represents the distribution of random noise in the sample. Since a higher difference in the +MG132/-MG132 ratio is a more "significant" result, the percentage of the random noise produced from 50,000 permutations that is higher in magnitude than the true difference (calculated from unpermuted data) is the $p$ value.

Permutations of a data point in a + MG132 into a group labeled -MG132 (or vice versa) were not allowed. This is because these permutations would produce an obviously significant result, as MG132 is a known proteasomal inhibitor that significantly increases ubiquitin levels in the cell. Thus, this group difference was not interesting to us.

To assess group differences in the autophagic flux assay, the two-sided Kolmogorov-Smirnov test was used. This nonparametric test determines the probability that two continuous, one-dimensional probability distributions are drawn from the same distribution or not.

\section{Results}

\section{$\mathrm{PR}_{20}$ added to media is taken up by neurons and results in death}

The difficulty of distinguishing between toxic HRE mRNA and DPR proteins has impeded our understanding of the mechanism underlying C9ORF72 HRE pathophysiology. As reported in Science (Kwon et al., 2014), the McKnight lab devised a strategy to overcome this problem: they studied U2OS cells and human astrocytes directly exposed to synthetic DPR proteins. They found that HA-tagged DPR proteins are taken up by these cells and evoke a variety of biochemical changes. $\mathrm{PR}_{20}$ and $\mathrm{GR}_{20}$ were shown to be toxic in a concentration range of 10-30 $\mu \mathrm{M}$ depending on the specific assay. We built upon this 
A

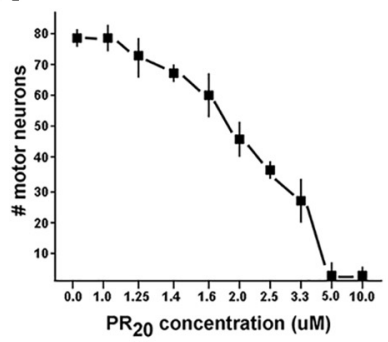

B

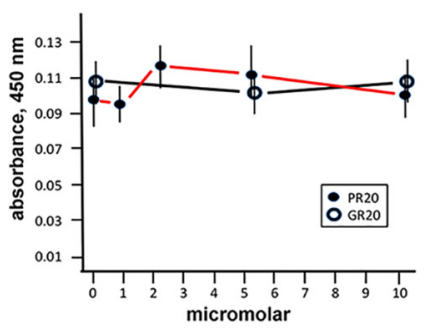

C

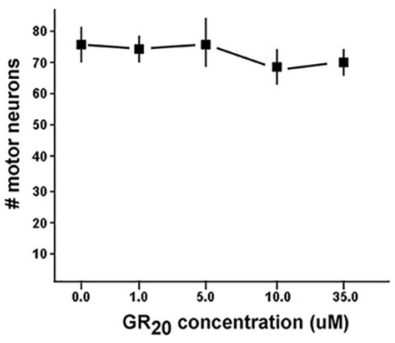

D

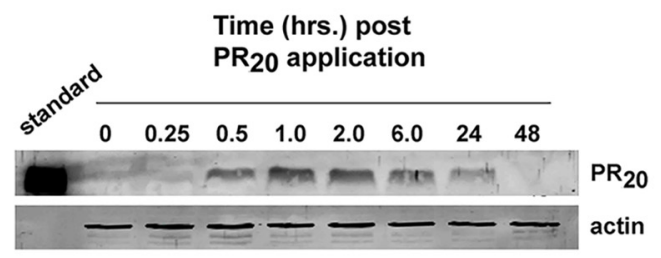

E

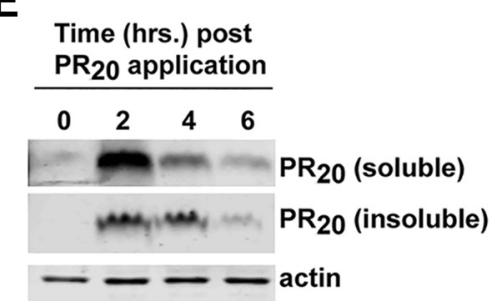

F

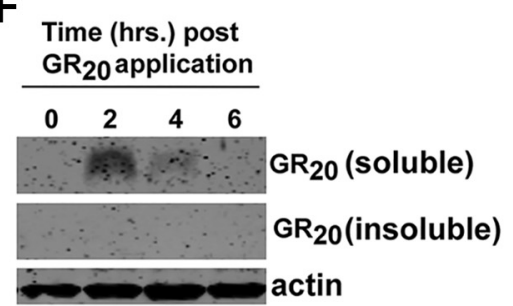

G

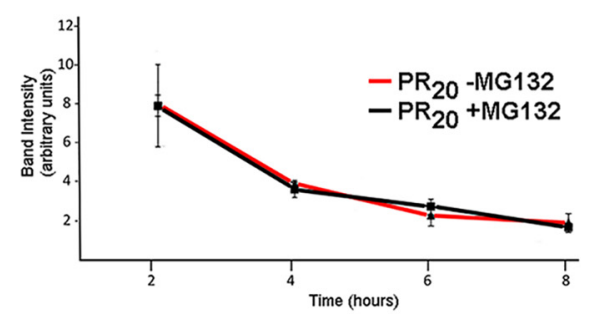

H

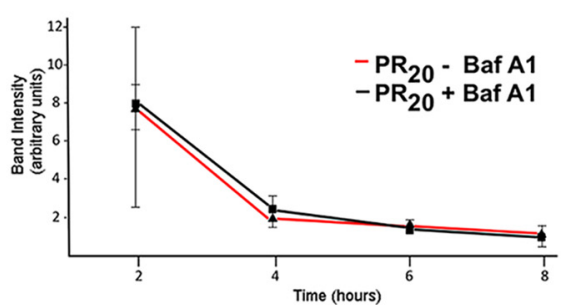

Figure 1. $\mathrm{PR}_{20}$, but not $\mathrm{GR}_{20}$, is toxic to motor neurons: kinetics of cellular accumulation and disposal. Mixed spinal cord neuron cultures or pure astrocyte cultures were exposed to $\mathrm{PR}_{20}$ - or $\mathrm{GR}_{20}$-containing media; survival assays and biochemical interrogations followed. $\boldsymbol{A}$, The survival of motor neurons was determined $5 \mathrm{~d}$ after exposure to various concentrations of $\mathrm{PR}_{20}$. The $\mathrm{LD}_{50}$ of $\mathrm{PR}_{20}$ is $\sim 2 \mu \mathrm{M}$. $\boldsymbol{B}$, The survival of astrocytes was determined using the colorimetric XTT assay $5 \mathrm{~d}$ after exposure to various concentrations of $\mathrm{PR}_{20}$ or $\mathrm{GR}_{20}$. No death was seen up to $10 \mu \mathrm{M}$ DPR. $\boldsymbol{C}$, The survival of motor neurons was determined $5 \mathrm{~d}$ after exposure to various concentrations of $\mathrm{GR}_{20}$. No death was seen up to $35 \mu \mathrm{M} \mathrm{GR} \mathrm{GO}_{20}$. $\boldsymbol{D}$, Immunoblotting for HA-tagged PR $\mathrm{PR}_{20}$ at various time points after addition of $2 \mu \mathrm{M} \mathrm{PR} 20$ to mixed spinal cord cultures. $\mathrm{PR}_{20}$ is first detectable in cell lysates approximately $0.5 \mathrm{~h}$ after exposure and rises to a maximum at 1.0-2.0 h. The Western blot signal declines thereafter and is undetectable at the 48-h time point. $\boldsymbol{E}$, In a 2-h pulse-chase paradigm after $2 \mu \mathrm{M} \mathrm{PR}_{20}$ application, Western blot signal is detectable in the soluble and insoluble fractions at the 2-h time point, and the signal diminishes thereafter to a barely detectable level by the 6-h time point. $\boldsymbol{F}$, In a 2-h pulse-chase paradigm after $10 \mu \mathrm{M} \mathrm{GR}$ application, Western blot signal is detectable in the soluble fraction only at the 2-h time point, and the signal diminishes thereafter to a barely detectable level by the 4-h time point. G. Mixed spinal cord cultures were pulsed for $2 \mathrm{~h}$ with $2 \mu \mathrm{M}$ $\mathrm{PR}_{20}$ and the chase media contained MG132 (5 $\left.\mu \mathrm{M}\right)$ or vehicle. Cell lysates were prepared at time intervals thereafter, and quantitative image analysis of the resultant Western blots showed that the decrement in $\mathrm{PR}_{20}$ abundance was the same in the + MG132 condition in comparison with the -MG132 condition. $\boldsymbol{H}$, Mixed spinal cord cultures were pulsed for $2 \mathrm{~h}$ with $2 \mu \mathrm{M} P R_{20}$, and the chase media contained bafilomycin A1 (Baf A1) (400 nM). Cell lysates were prepared at time intervals thereafter, and quantitative image analysis of the resultant Western blots showed that the decrement in $\mathrm{PR}_{20}$ abundance was the same in the +Baf $\mathrm{A} 1$ condition in comparison with the -Baf A1 condition.

approach by applying synthetic, HA-tagged, $\mathrm{PR}_{20}$ or $\mathrm{GR}_{20}$ dipeptides to cultures of rat spinal cord neurons grown on an astrocyte feeder layer, referred to as mixed spinal cord cultures hereafter. We find that $\mathrm{PR}_{20}$ is toxic to cells: $5 \mathrm{~d}$ after a single application of $\mathrm{PR}_{20}$, we observe the death of motor neurons with a $L_{50}$ of $2 \mu \mathrm{M}$ (Fig. $1 A$ ). No significant motor neuron death was seen with $2 \mu \mathrm{M} \mathrm{PR} \mathrm{PR}_{20}$ at the 48-h time point. In pure astrocyte cultures, we found no cell death when $\mathrm{PR}_{20}$ was applied up to $10 \mu \mathrm{M}$ (Fig. 1B). In this assay, $\mathrm{GR}_{20}$ was neither toxic to motor neurons when administered up to $35 \mu \mathrm{M}$ (Fig. 1C) nor astrocytes when administered up to $10 \mu \mathrm{M}$ (Fig. 1B).

Kwon et al. (2014) show that 30 min after application to U2OS cells or human astrocytes, $\mathrm{PR}_{20}$ accumulates in the nucleus, colocalizing with the nucleolar protein fibrillin. This demonstrates that cells can take up extracellular DPR proteins, which is consistent with the recent demonstration of cell-to-cell transfer of DPRs in vitro (Westergard et al., 2016). We investigated the fate of $\mathrm{PR}_{20}$ in mixed spinal cord cultures through immunoblotting and 
immunocytochemistry. After application of $2 \mu \mathrm{M} \mathrm{PR}_{20}$, the immunoblot signal is first detected after $30 \mathrm{~min}$ and is maximal at the 1- to 2-h time points (Fig. 1D). Despite the continual presence of $\mathrm{PR}_{20}$ in the media, the immunoblot signal diminishes over time and is undetectable at the 48-h time point. To gain further insight into the kinetics of the observed decrease in $\mathrm{PR}_{20}$ levels in cell lysates over time, we pulsed cells with $2 \mu \mathrm{M} \mathrm{PR}_{20}$ for $2 \mathrm{~h}$, washed, replaced with fresh media (lacking $\mathrm{PR}_{20}$ ), and made cell lysates at regular intervals thereafter. Upon probing for $\mathrm{PR}_{20}$ in the soluble and insoluble fractions of cell lysates, we saw maximal immunoreactivity at the 2-h time point and a rapid decline in soluble and insoluble $\mathrm{PR}_{20}$ over the subsequent $4 \mathrm{~h}$ (Fig. 1E). After a single 2-h application of $2 \mu \mathrm{M} \mathrm{GR}_{20}$, the peptide is weakly detectable by immunoblotting in mixed spinal cord lysates. To more easily follow $\mathrm{GR}_{20}$ by immunoblotting, we applied $10 \mu \mathrm{M} \mathrm{GR}_{20}$ to cultures and performed the same kinetic analysis as described in Figure $1 D$. In this assay system, $\mathrm{GR}_{20}$ is detectable in cell lysates as early as 15 min and maximally accumulates in cells over the first hour of exposure. $\mathrm{GR}_{20}$ immunoblot signal falls off rapidly thereafter and is undetectable at the 24-h time point. In the pulse-chase assay, $\mathrm{GR}_{20}$ is maximal at the 2-h time point (immediately after the removal of $\mathrm{GR}_{20}$ containing media) and is rapidly cleared from the soluble fraction of cells over the next 2-4 $\mathrm{h}($ Fig. $1 F) . \mathrm{GR}_{20}$ is not detectable in the insoluble fraction under these assay conditions. To determine whether the proteasome was involved in the decrease in $\mathrm{PR}_{20}$ abundance, we compared the kinetics of the $\mathrm{PR}_{20}$ signal when MG132 or vehicle was included in the chase media. The loss of $\mathrm{PR}_{20}$ was indistinguishable under these two conditions (Fig. 1G). Parallel studies using bafilomycin A1 in the chase media indicated that the lysosomal-autophagy system was similarly uninvolved in the decrease abundance in PR20 over time (Fig. 1H).

Immunocytochemical examination at the 2-h time point reveals nuclear $\mathrm{PR}_{20}$ immunoreactivity in motor neurons [identified by colocalization with a validated motor neuron marker, SMI32 (Mojsilovic-Petrovic et al., 2006); Fig. $2 A--C]$ and other cells including astrocytes (Fig. $2 D--F$ ). Irregularly-shaped punctate accumulations of $\mathrm{PR}_{20}$ immunoreactivity are also visible; some appear to be intracellular and others extracellular (best seen in Figure 2B,E). Immunocytochemical examination of mixed spinal cord cultures exposed to $2 \mu \mathrm{M} \mathrm{GR} 20$ for $2 \mathrm{~h}$ reveals cytosolic $\mathrm{GR}_{20}$ immunoreactivity in motor neurons and other cells (Fig. 2G--l), but not astrocytes (Fig. 2J--L).

We draw a number of conclusions from these experiments. First, $\mathrm{PR}_{20}$ is toxic to motor neurons with an $\mathrm{LD}_{50}$ of $2.0 \mu \mathrm{M}$, a value that is $25 \%$ of the $L_{50}$ of $8.4 \mu \mathrm{M}$ reported by Kwon et al. (2014) that kills human astrocytes. We do not see the astrocytic DPR toxicity which we attribute to procedural differences: (1) Kwon et al. used human astrocytes, whereas we used freshly prepared rat astrocytes; and (2) we applied DPRs once, whereas Kwon et al. did so repeatedly.

Second, when cells contain the maximal amount of $\mathrm{PR}_{20}$ (approximately $2 \mathrm{~h}$ after treatment), we observe that it accumulates in the nuclei of neurons and astrocytes. As such, $\mathrm{PR}_{20}$ acting directly on neurons may be noxious and/or a sublethal insult to astrocytes might be contributing to motor neuron death. Although punctate accumulations of $\mathrm{PR}_{20}$, as reported previously (Wen et al., 2014), are also visible, the extent to which nuclear or punctate $\mathrm{PR}_{20}$ confers toxicity is not known.

Third, even at a $\sim 20$ times higher concentration, $\mathrm{GR}_{20}$ is not toxic to motor neurons. When cells contain the maximal amount of $\mathrm{GR}_{20}$ (approximately $2 \mathrm{~h}$ after treatment), we find that it selectively accumulates in the cytosol of neurons only. Possible explanations for the benignity of $\mathrm{GR}_{20}$ in our system are that the nucleus is the site of DPR protein toxicity and/or that astrocytes contributor to motor neuron injury. The absence of $\mathrm{GR}_{20}$ in either or both of these locales apparently renders motor neurons largely insensitive to $\mathrm{GR}_{20}$.

Fourth, $\mathrm{PR}_{20}$ accumulates to a higher degree and for a longer time than $\mathrm{GR}_{20}$ in cells, although the half-life of these dipeptides is similar (on the orders of hours). Neither the ubiquitin-proteasome nor the lysosome-autophagy pathway is likely to be responsible for the time-dependent loss of $\mathrm{PR}_{20}$. Owing to how we crafted the sensitivity of Western blotting for DPR proteins, we are probably underestimating the relative abundance of these proteins in our cell lysates. Thus, we suspect that DPR proteins are not completely eliminated from cells within $48 \mathrm{~h}$. It is noteworthy that $\mathrm{HA}$-tagged $\mathrm{PR}_{20}$ and $\mathrm{GR}_{20}$ have similar molecular weights (6.1 vs $5.3 \mathrm{kDa}$, respectively) and identical calculated isoelectric point (e.g., $\mathrm{pl}=12.37$ ). This suggests that the biological effects of small basic peptides are sequence dependent, implying that they interact with distinct intracellular molecules.

\section{$\mathbf{P R}_{20}$ does not significantly impact $\mathbf{m T O R C}$, ER stress, or mitochondrial dysfunction}

Cell and animal models of ALS based on the expression of mutant proteins that cause familial ALS (e.g., mTDP43, mSOD1) have implicated reduced mTORC activity, mitochondrial dysfunction, and ER stress (Kong and Xu, 1998; Lim et al., 2012; Betz and Hall, 2013; Saxena et al., 2013; Perera et al., 2014) in the pathophysiology. To understand the mechanism underlying DPR protein toxicity, we asked whether $\mathrm{PR}_{20}$ evoked similar biochemical changes in cells.

Upon treating cultures with $2 \mu \mathrm{M} \mathrm{PR}_{20}$ for $48 \mathrm{~h}$, we used immunoblotting techniques to probe for these biochemical changes (Fig. $3 A, B$ ). We see no statistically significant differences in the activation level of the mTOR pathway (monitored by the abundance of phosphorylated S6K and 4EBP1), mitochondrial dysfunction (monitored by the abundance of phosphorylated AMPK), or ER stress (monitored by the abundance of KDEL-tagged chaperones BiP and PDI). Biochemical interrogations at earlier time points similarly show no effect of $\mathrm{PR}_{20}$ on these pathways (data not shown). These observations suggest that in this experimental paradigm, $\mathrm{PR}_{20}$ does not influence pathways previously implicated in mTDP43 and mSOD toxicity. One caveat here is that our culture system contains astrocytes, motor neurons, and other neurons and biochemical changes within a subpopulation of cells might be ob- 

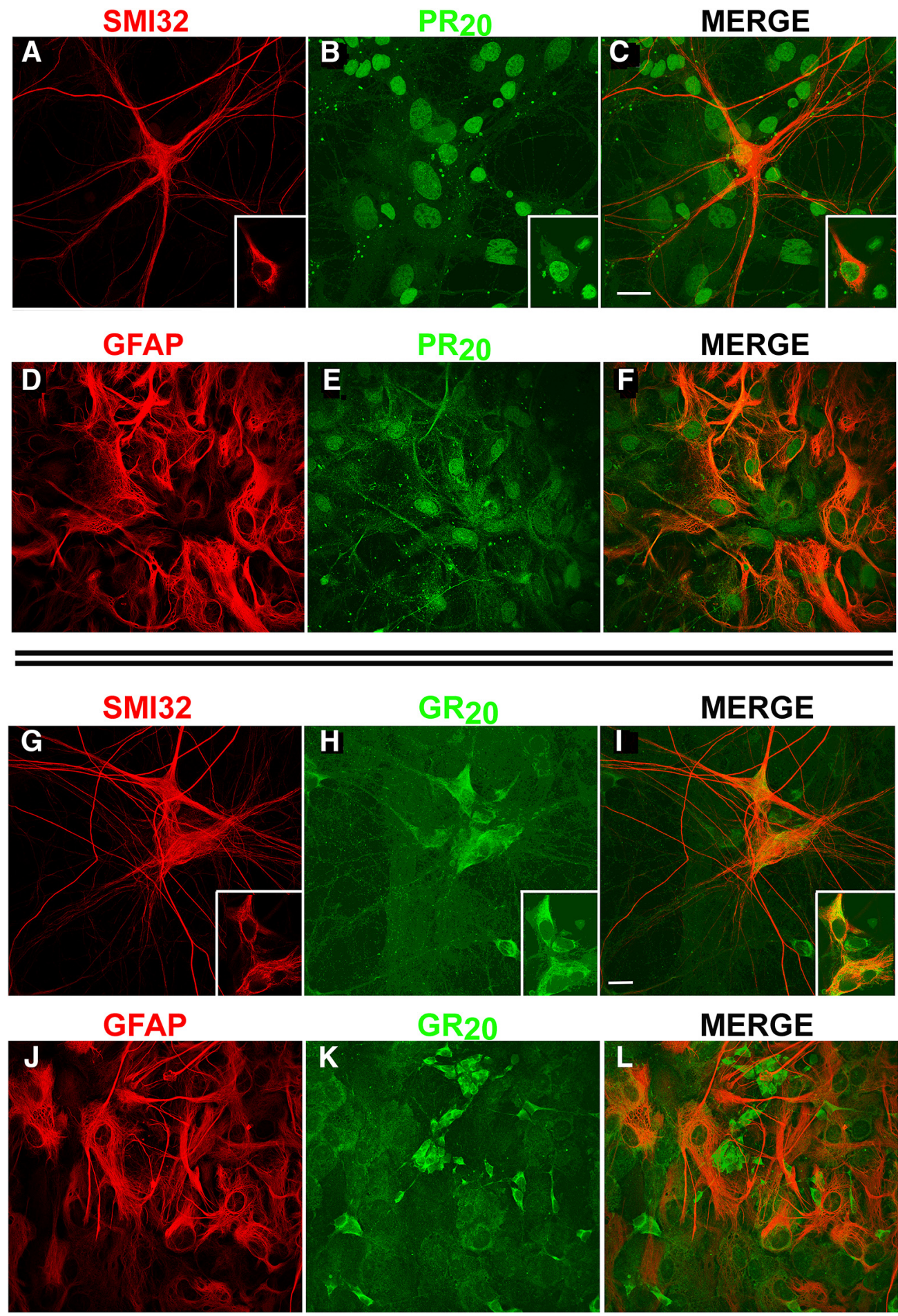

Figure 2. $\mathrm{PR}_{20}$ and $\mathrm{GR}_{20}$ accumulate in distinct subcellular locations and distinct cell populations. Mixed spinal cord cultures were exposed to $2 \mu \mathrm{M} \mathrm{PR} 20$ or $\mathrm{GR}_{20}$ for $48 \mathrm{~h}$, fixed, and processed for immunocytochemistry. $\boldsymbol{A}$, Staining with SMI32 reveals large multipolar motor neurons. The inset shows a single $0.5-\mu \mathrm{m}$ slice from the confocal data at the level of the nucleus. $\boldsymbol{B}$, The same field as in $\mathbf{A}$, stained for $\mathrm{HA}-\mathrm{PR}_{20}$ reveals nuclear staining as well as scattered puncta. The inset shows a single $0.5-\mu \mathrm{m}$ slice at the same level as in (A), suggesting nuclear $\mathrm{PR}_{20}$ in the motor neuron. $\boldsymbol{C}, \mathrm{A}$ merge image of $\boldsymbol{A}$ and $\boldsymbol{B}$ reveals nuclear $\mathrm{PR}_{20}$ in multiple cells, including the labeled motor neuron. The inset shows the same single $0.5-\mu \mathrm{m}$ slice from $\boldsymbol{A}$ and $\boldsymbol{B}$ unambiguously demonstrating $P R_{20}$ immunoreactivity in motor neurons. Calibration bar $=35 \mu \mathrm{m}$. $\boldsymbol{D}$, Staining for GFAP reveals abundant astrocytes in these cultures. $\boldsymbol{E}$, The same field as in $\boldsymbol{D}$, stained for $\mathrm{HA}-\mathrm{PR}_{20}$ reveals nuclear staining as well as scattered puncta. $\boldsymbol{F}$, A merge image of $\boldsymbol{D}$ and $\boldsymbol{E}$ reveals nuclear $\mathrm{PR}_{20}$ in astrocytes. G. Mixed spinal cord cultures were exposed to $2 \mu \mathrm{M} \mathrm{GR}_{20}$ for $48 \mathrm{~h}$, fixed, and processed for immunocytochemistry. Staining with SMI32 reveals large multipolar motor neurons. Inset shows a single $0.5-\mu \mathrm{m}$ slice from the confocal data at the level of the nucleus. $\boldsymbol{H}$, The same field as in $\boldsymbol{G}$, stained for $\mathrm{HA}-\mathrm{GR}_{20}$ reveals cytoplasmic staining. Inset show a 
continued

single $0.5-\mu \mathrm{m}$ slice at the same level as in $\mathbf{G}$, suggesting cytoplasmic $\mathrm{GR}_{20}$ in the motor neuron. $\boldsymbol{I}$, A merge image of $\boldsymbol{G}$ and $\boldsymbol{H}$ reveals cytoplasmic $\mathrm{GR}_{20}$ in multiple cells, including the labeled motor neurons. Inset shows the same single $0.5-\mu \mathrm{m}$ slice from the $\boldsymbol{G}$ and $\boldsymbol{H}$ unambiguously demonstrating $\mathrm{GR}_{20}$ immunoreactivity in motor neurons. Calibration bar $=30 \mu \mathrm{m}$. J, Staining for GFAP reveals abundant astrocytes in these cultures. $\boldsymbol{K}$, The same field as in $\boldsymbol{J}$ stained for HA-GR $\mathbf{R}_{20}$ reveals cytoplasmic staining. $\boldsymbol{L}$, A merge image of $\boldsymbol{J}$ and $\boldsymbol{K}$ reveals cytoplasmic $\mathrm{GR}_{20}$ is not present in astrocytes.

scured when we generate cell lysates from this heterogeneous cell population. The cost of using maximally healthy astrocyte/neuronal cocultures that approximate the in vivo complexity of cell-cell interactions is the difficulty of studying the biochemistry of a distinct subtype of neuron.

\section{$\mathrm{PR}_{20}$ induces cytoplasmic degradation dysfunction through diminished proteasomal flux}

A variety of disease-causing proteins can cause UPS inhibition (Bence et al., 2001). Thus, we asked whether $\mathrm{PR}_{20}$ influences the ubiquitylation status of the proteome over time. Upon immunoblotting for total cellular ubiquitin at various time points after the application of $\mathrm{PR}_{20}$ (vs vehicle) to cultures, we find that $\mathrm{PR}_{20}$ treatment is asso- ciated with a progressive increase in total ubiquitylated protein levels. This is statistically significant at the 2-, 8-, and 16-h time points (Fig. 4A). We considered the possibility that the smear of ubiquitin immunoreactivity might contain $\mathrm{PR}_{20}$ immunoreactivity. When we performed immunoblots for $\mathrm{HA}$ in these samples, we saw all the $\mathrm{PR}_{20}$ immunoreactivity ran at $\sim 10 \mathrm{kDa}$, the molecular weight we see of pure peptide (Fig. 4A.). Thus, this assay provides no evidence that $\mathrm{PR}_{20}$ is ubiquitylated.

The increase in the steady-state amount of ubiquitin over time could be attributed to an increase in the rate of ubiquitylation or a decrease in the rate of degradation of ubiquitylated substrates (Fig. 4B). This is analogous to the autophagy protein LC3-II whose increased abundance in

A
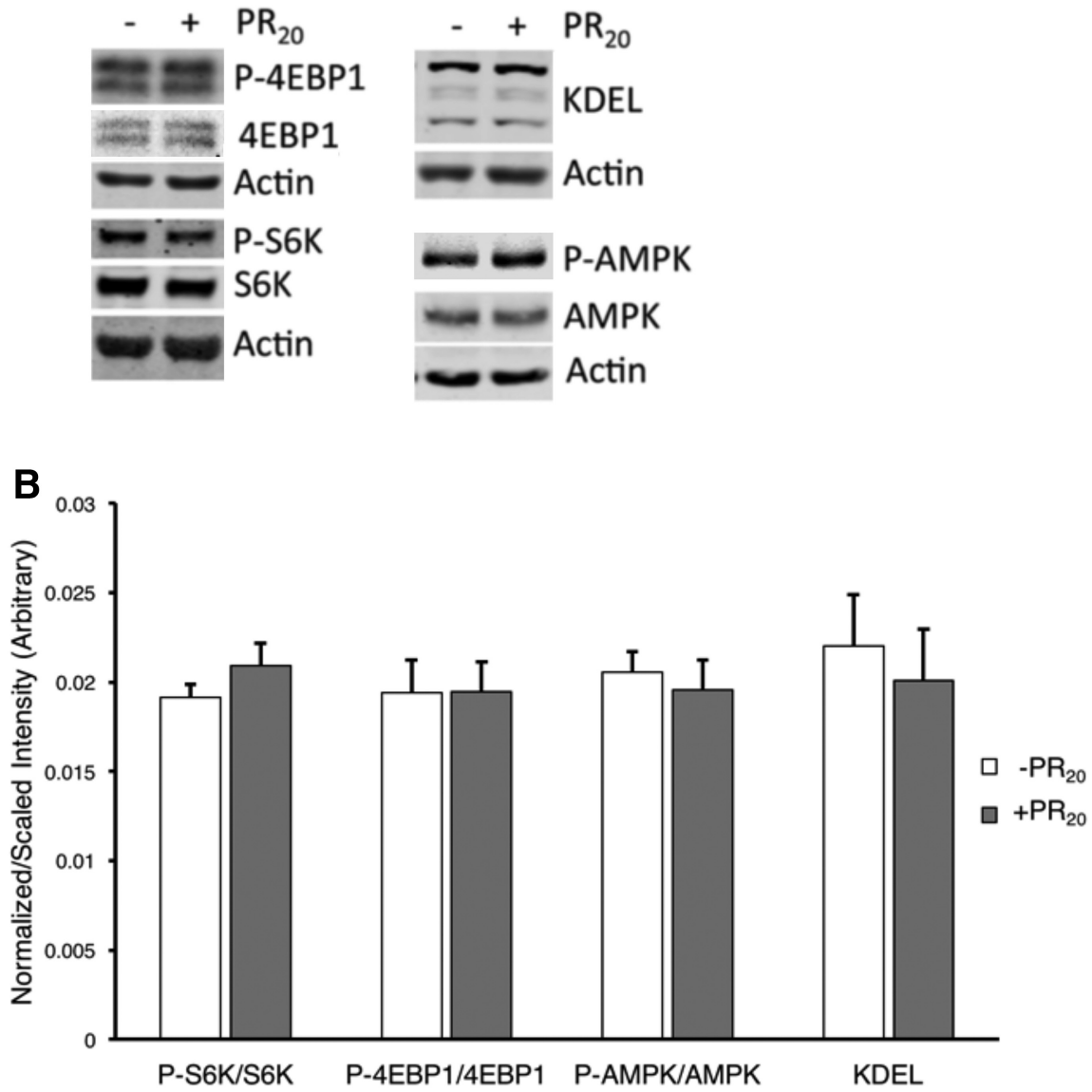

Figure 3. $\mathrm{PR}_{20}$ neither influences the activation of TORC or AMPK nor ER stress. Mixed spinal cord cultures were exposed to PR 20 for $48 \mathrm{~h}$ and then processed for immunoblotting. $\boldsymbol{A}$, Representative immunoblot images of biochemical markers of TORC activation (e.g., phospho-4EBP1 and phospho-S6K), AMPK activation, or activation of the ER stress response (KDEL) shows no difference between $\mathrm{PR}_{20}$ versus vehicle-treated cells. $\boldsymbol{B}$, Quantification of the bands with intensity values from samples were averaged and normalized to actin loading controls. Dark grey bars correspond to the presence of $\mathrm{PR}_{20}$, and light grey bars correspond to levels without $\mathrm{PR}_{20}$. Error bars represent SE. 


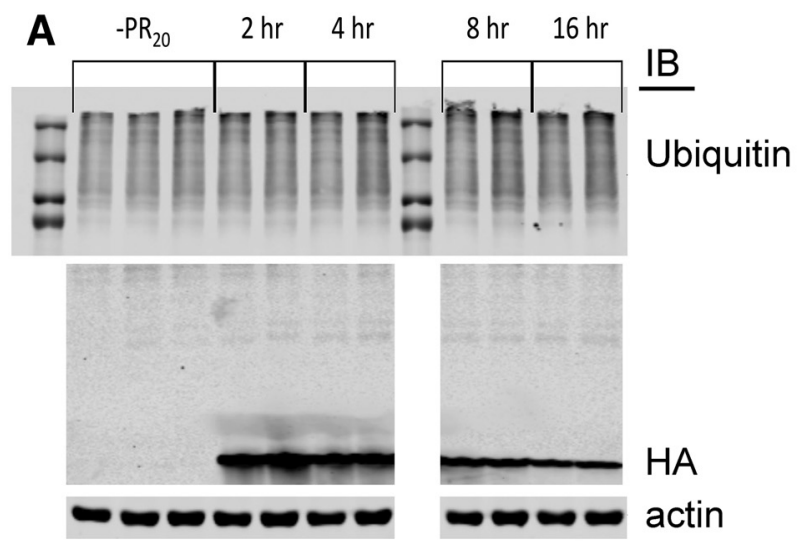

B
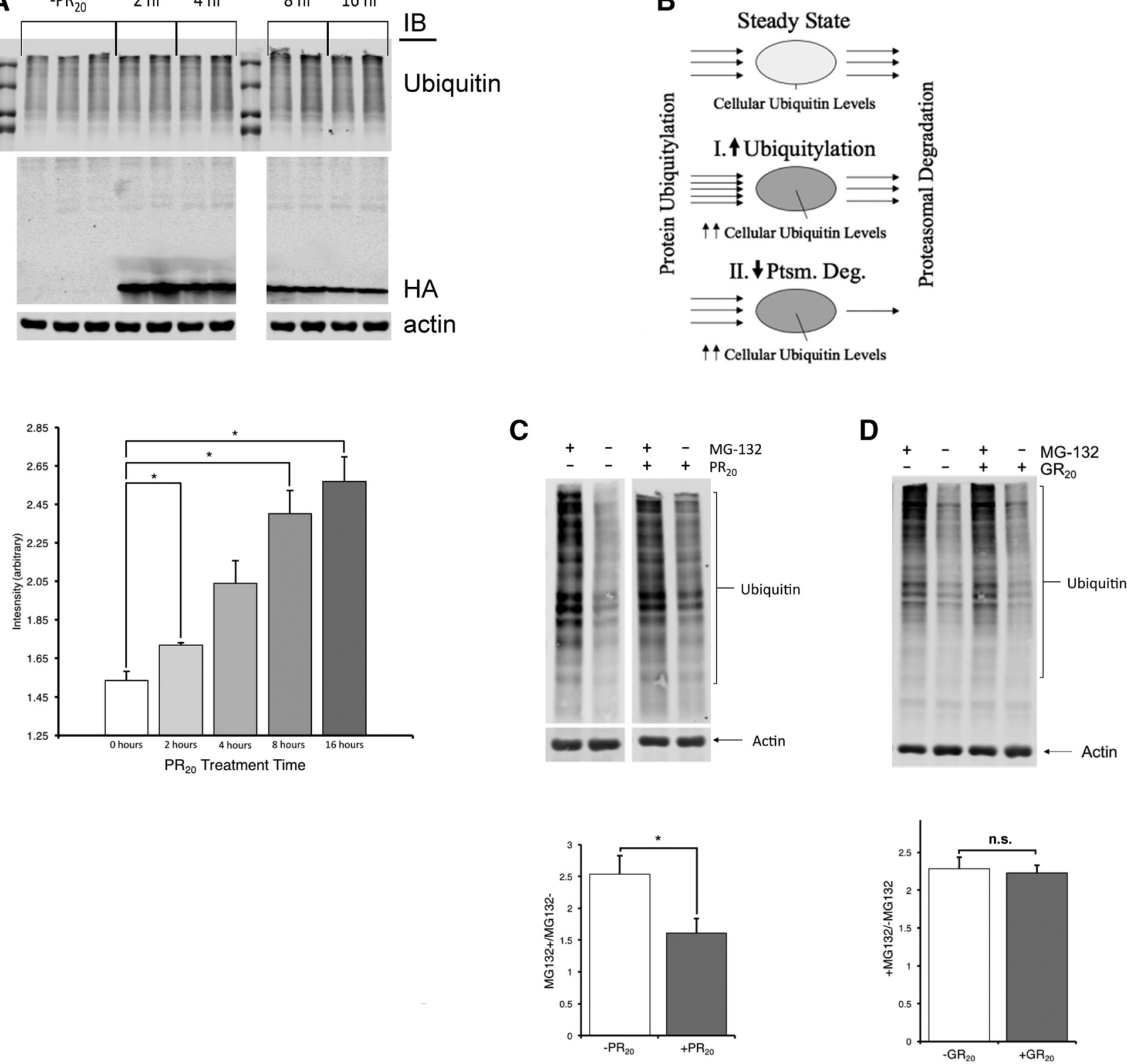

Figure 4. Total ubiquitin levels rise over time in the presence of $P R_{20} ; \mathrm{PR}_{20}$, but not $\mathrm{GR}_{20}$, inhibits substrate flux through the ubiquitin-proteasomal system. Mixed spinal cord cultures were exposed to $\mathrm{PR}_{20}$ or $\mathrm{GR}_{20}$ and subjected to biochemical interrogations. $\boldsymbol{A}$, Duplicate or triplicate cell lysate samples probed for ubiquitin in the absence of $\mathrm{PR}_{20}\left(-\mathrm{PR}_{20}\right)$ or at $2,4,8$, or $16 \mathrm{~h}$ after $\mathrm{PR}_{20}$ application. A progressive build-up in total ubiquitin levels occurs over time. The panel below shows quantification of these data with total ubiquitin levels normalized to actin loading controls. Error bars represent SE. Blotting for HA-tagged PR $\mathrm{R}_{20}$ shows that DPR is present in the lysates but does not migrate as a high molecular weight species as would be expected if $P_{20}$ was ubiquitylated. Equal amounts of total protein are present in each lane, as reported by the actin blot. $\boldsymbol{B}$, Cartoon describing two different mechanisms for increased steady state ubiquitin levels: enhanced ubiquitylation versus decreased proteasomal degradation. $\boldsymbol{C}$, Total ubiquitin levels from cells treated with $\mathrm{PR}_{20}$ or vehicle for $48 \mathrm{~h}$ and then MG132 or vehicle for $4 \mathrm{~h}$. The difference between the $+/-$ MG132 lanes represents the flux of ubiquitylated substrates over $4 \mathrm{~h}$. Representative ubiquitin blots demonstrate a smaller difference between the $+/$ - MG132 lanes in $\mathrm{PR}_{20}$-treated cultures versus vehicle-treated cultures. The permutation test was applied to determine whether statistically significant group differences exist, and the results are shown in the lower panel. There is a reduced flux of ubiquitylated substrates in the $\mathrm{PR}_{20}$-treated cells versus vehicle-treated cells. Six independent biological replicates were tested for each condition. $*, p<0.05$ by the permutation test. $\boldsymbol{D}$, Representative ubiquitin blots demonstrate no difference between the +/- MG132 lanes in $\mathrm{GR}_{20}$-treated cultures versus vehicle-treated cultures. The permutation test was applied to determine whether statistically significant group differences exist, and the results are shown in the lower panel. No group differences were found, and at least 10 independent biological replicates were tested for each condition. n.s., not significant. 
cells under certain conditions can be attributed to an increase in the rate of production or a decrease in the rate of degradation (which reflects increased or decreased flux through the lysosomal-autophagy pathway, respectively). Although several approaches can be taken to resolve the mechanism, in the autophagy field, the turnover assay is most widely used: the difference in LC3-II levels between samples with or without an autophagy inhibitor (i.e., chloroquine or bafilomycin A1) is used to report flux (Mizushima et al., 2010; Klionsky et al., 2012). We have taken a similar approach here using MG-132, a potent proteasomal degradation inhibitor (Goldberg, 2012). The difference in the quantity of ubiquitylated proteins from cells treated with MG-132 for $4 \mathrm{~h}$ versus vehicle reflects the size of the ubiquitylated protein pool normally degraded by the UPS. The larger the difference, the more proteins are degraded. Thus, this is a measure of flux through the UPS.

Parallel sets of mixed cultures were treated with $\mathrm{PR}_{20}$ or vehicle for $48 \mathrm{~h}$, and subsequent experimental groups were treated with MG-132 or vehicle for $4 \mathrm{~h}$. Upon lysis, whole-cell ubiquitin levels were determined through immunoblotting. The average of these was taken for the cases with and without $\mathrm{PR}_{20}$. A two-tailed permutation test was performed with 50,000 iterations, and statistically significant $(p<0.05)$ group differences were found; proteasomal flux was reduced in the presence of $\mathrm{PR}_{20}$ (Fig. $4 C)$. In parallel, we examined the effect of $\mathrm{GR}_{20}$ on total ubiquitin levels with or without MG-132. $\mathrm{GR}_{20}$ neither influenced total ubiquitin levels nor proteasomal flux (Fig. 4D). Together with the finding of elevated total ubiquitylated protein levels in $\mathrm{PR}_{20}$-treated (but not $\mathrm{GR}_{20}$-treated) cultures over time, these observations suggest that $\mathrm{PR}_{20}$ specifically acts as a proteasomal inhibitor.

We wondered how soon after application to cultures did $\mathrm{PR}_{20}$ inhibit proteasomal flux. Specifically, at the time point when $\mathrm{PR}_{20}$ appears maximally within cells (i.e., $2 \mathrm{~h}$; see Figure 1D), was proteasomal flux impaired? We repeated the \pm MG132 flux assay after $2 \mathrm{~h}$ of $\mathrm{PR}_{20}$ exposure and found no statistically significance between the $\mathrm{PR}_{20}$ versus vehicle-treated cells by permutation test ( $n=6$ per experimental group, 4 experimental groups, $p=0.38$ ). This observation suggest that $\mathrm{PR}_{20}$ accumulation in cells does not instantaneously lead to proteasomal inhibition. We suspect that the lag between $\mathrm{PR}_{20}$ internalization and proteasomal inhibition is an "access" issue, and perhaps this is linked to ephemeral sequestration of DPR proteins in nonmembrane delimited compartments as recently demonstrated by the Taylor and McKnight labs (Lee et al., 2016; Lin et al., 2016). We did not look at time points later than $48 \mathrm{~h}$, because we feared cell morbidity and mortality could have secondary effects on proteasomal function and thus lead to interpretative difficulties.

Since all of these biochemical experiments were performed on mixed spinal cord cultures, it is possible that the effects of $\mathrm{PR}_{20}$ are more or less robust within a specific subpopulation of cells. Although the simplest conclusion is that all cells taking up $\mathrm{PR}_{20}$ are manifesting the same biochemical phenotype, deployment of cell- type-specific reporters of UPS flux could reveal differences otherwise obscured by our Western blots.

\section{Autophagic flux is reduced in the presence of $\mathbf{P R}_{\mathbf{2 0}}$}

We next asked whether $\mathrm{PR}_{20}$ influences flux through the lysosomal-macroautophagy pathway (referred to as autophagy hereafter) as well. As mentioned above, one commonly used biochemical approach is to monitor changes in the amount of 1A/1B-LC3, a microtubuleassociated protein that acts as both an autophagy marker and substrate, in the presence or absence of an autophagy inhibitor (Mizushima et al., 2010; Klionsky et al., 2016). Unfortunately, this approach is not well suited to investigations using mixed cultures because of the difficulty of resolving the active, lipidated form of LC3, termed LC3-II, from the unmodified LC3-I using immunoblot techniques (Zhai et al., 2015). Moreover, traditional immunoblotting and immunocytochemical techniques can be insensitive and are often difficult to accurately quantify. To overcome these problems, we adopted an optical pulse labeling approach (Tsvetkov et al., 2013; Barmada et al., 2014) to monitor autophagic flux. In this technique, a Dendra2-LC3 fusion protein is introduced into cells. Upon exposure to 405-nm light, the excitation and emission spectra of Dendra2 are irreversibly red shifted. Because LC3 is an autophagy substrate, the rate of Dendra2-LC3 degradation (estimated by the time-dependent loss of red fluorescence) represents a measure of autophagic flux (Koga et al., 2011; Tsvetkov et al., 2013; Barmada et al., 2014; Loos et al., 2014). An example of this phenomenon is shown in Figure $5 A$.

Primary spinal neurons were transfected with a plasmid encoding Dendra2-LC3, and subject to optical pulse labeling using automated longitudinal fluorescence microscopy (Barmada et al., 2014). The half-life of Dendra2-LC3 was measured in thousands of primary spinal neurons on single-cell basis. Four experiment groups were investigated: (1) Dendra2-LC3 + vehicle; (2) Dendra2-LC3 + $\mathrm{GR}_{20}$; (3) Dendra2-LC3 + $\mathrm{PR}_{20}$; and (4) Dendra2-LC3 + MG132. We observed a wide distribution of neuronal Dendra2-LC3 half-lives in all groups (Fig. 5B), consistent with previous studies (Barmada et al., 2014). Treatment with $2 \mu \mathrm{M} \mathrm{PR}_{20}$ peptide led to a significant shift in the population distribution, with a reduction in the peak around $\sim 20 \mathrm{~h}$ and a longer tail of half-lives Dendra2-LC3 (Fig. 5B). Compared with the control, treatment with $\mathrm{PR}_{20}$ extended the half-life of Dendra2-LC3 by $\sim 5.6 \mathrm{~h}(p=2 \times$ $\left.10^{-16}\right)$. Compared with the control, treatment with $\mathrm{GR}_{20}$ to increase the half-life of Dendra2-LC3 by $1.5 \mathrm{~h}(p=$ 0.0038). Finally, compared with the control, MG132 led to a more marked rightward shift of the curve, and this treatment extended the half-life by $11.9 \mathrm{~h}(p=2.2 \times$ $\left.10^{-16}\right)$.

Next, we looked at the distribution of Dendra2 half-lives operating under the presumption that this soluble cytosolic protein is likely to be degraded by the UPS (Fig. $5 C$ ). Four experiment groups were investigated: (1) Dendra2 + vehicle, (2) Dendra2 $+\mathrm{GR}_{20}$, (3) Dendra2 $+\mathrm{PR}_{20}$, and (4) Dendra2 + MG132. Compared with the vehicle, MG132 treatment led to a marked rightward shift of the curve and 
A

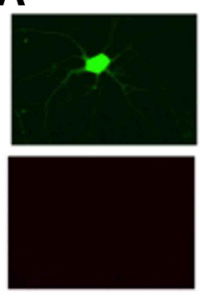

$\mathrm{OH}$

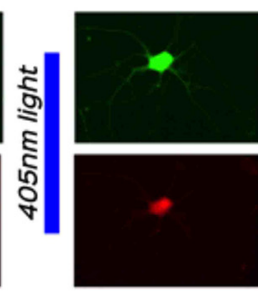

$\mathrm{OH}$

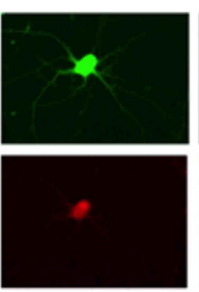

$4 \mathrm{H}$

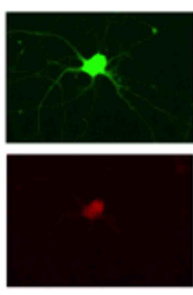

$8 \mathrm{H}$

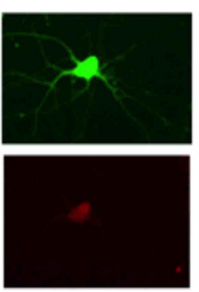

$12 \mathrm{H}$

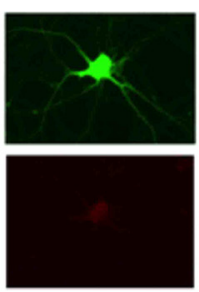

$22 \mathrm{H}$

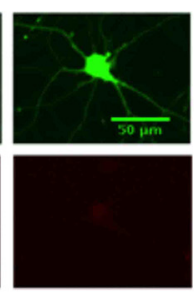

$42 \mathrm{H}$
B

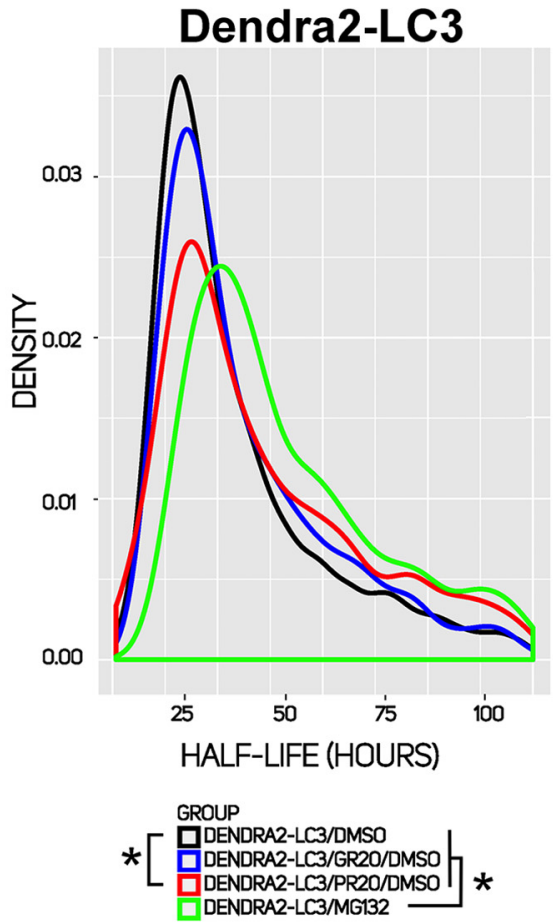

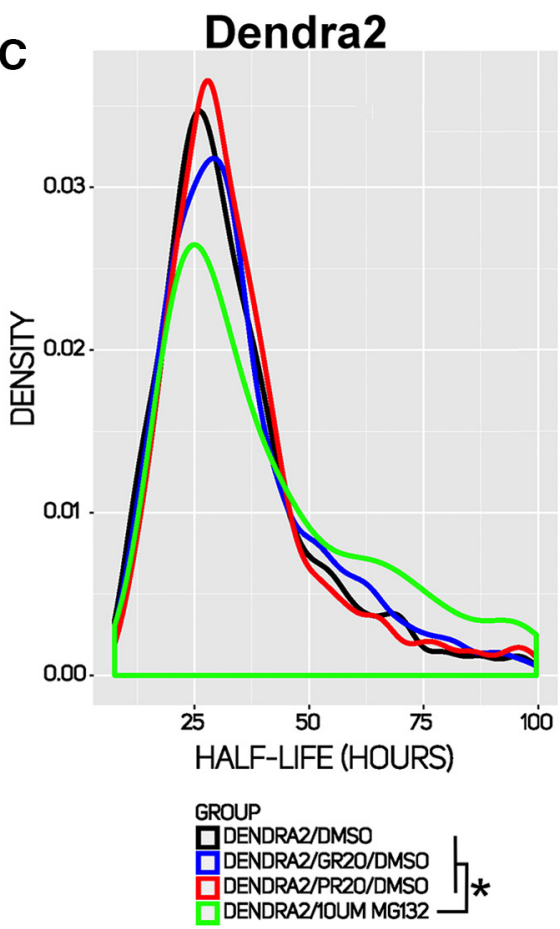

Figure 5. $\mathrm{PR}_{20}$ inhibits flux through the lysosomal-autophagy system. $A$, Optical pulse labeling of spinal neurons using automated fluorescent microscopy. Following a pulse of 405-nm light, a portion of Dendra2-LC3 is photoconverted such that its peak emission is red-shifted to $573 \mathrm{~nm}$. By measuring the decay in intensity using a TRITC filter, half-life can be determined in individual neurons. The half-life of Dendra2-LC3 is a measurement of autophagosome turnover, with an increased half-life indicating reduced turnover.

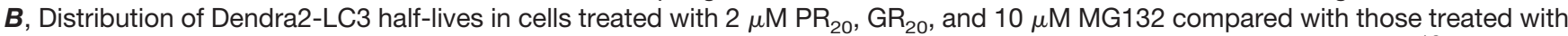
vehicle. $*$ indicates $p<.05$ with the two-sided Kolmogorov-Smirnov (KS) test $\left(\mathrm{GR}_{20} p=0.0038, \mathrm{PR}_{20} p=2.2 \times 10^{-16}, \mathrm{MG} 132 p\right.$ $\left.=2.2 \times 10^{-16}\right) . C$, MG132 significantly extends Dendra2 half-life while $2 \mu \mathrm{M} \mathrm{PR}_{20}$ and $\mathrm{GR}_{20}$ do not $\left(\mathrm{MG} 132 p=3.23 \times 10^{-5}\right.$, two-sided KS test).

the difference between the Dendra2 half-life in MG132 versus vehicle-treated cells ( 32.3 vs $29.6 \mathrm{~h}$ ) was statistically significant $\left(p=3.23 \times 10^{-5}\right)$. Dendra2 half-life in $\mathrm{PR}_{20^{-}}$or $\mathrm{GR}_{20^{-}}$-treated cultures $(30.5$ and $31.0 \mathrm{~h}$, respectively) did not differ in a statistically significant manner from vehicle-treated cells.

We draw a number of conclusions from these results. First, $\mathrm{PR}_{20}$ (and to a far lesser extent $\mathrm{GR}_{20}$ ) retards flux through the autophagy pathway. Second, to the degree that Dendra2 is degraded by the UPS, $\mathrm{PR}_{20}$ and $\mathrm{GR}_{20}$ had no statistically significant effect. Together, these observations suggest that $\mathrm{PR}_{20}$ acts in a relatively selective manner to slow flux through the autophagy pathway. Third, inhibition of the proteasome impairs autophagic flux. This was an unexpected observation, since several prior studies using cell lines have reported autophagy induction upon UPS inhibition (Ding et al., 2007; Lan et al., 2015; Bao et al., 2016). Our findings in neurons may indicate a cell-type-specific relationship between degradative pathways. Alternatively, a nonspecific toxicity to the autophagy pathway may occur when cell function is impaired by UPS blockage. Future work will be required to understand this effect of MG132 on autophagy in neurons.

\section{$\mathrm{PR}_{20}$ imparts direct inhibitory effects on the proteasome in vitro}

Considering the major role of the proteasome in the degradation of ubiquitylated substrates, we focused on the effects of $\mathrm{PR}_{20}$ on the UPS. $\mathrm{PR}_{20}$ could impede UPS 
flux in a variety of ways, such as: (1) reducing access of ubiquitylated substrates to the proteasome and their proper presentation by shuttle factors, (2) increasing deubiquitylation, (3) impeding transiting of substrates into the catalytic core of the proteasome, or (4) inhibiting proteolysis. To help distinguish among these possibilities, we began by asking whether $\mathrm{PR}_{20}$ directly associates with proteasomes. Cell lysates from HEK293T cells engineered to express biotinylated proteasomes were incubated with $\mathrm{PR}_{20}$ or $\mathrm{GR}_{20}$. Avidin-coated beads were then used to purify proteasomes, and the pulldown material was subjected to immunoblotting. We find that $\mathrm{PR}_{20}$, but not $\mathrm{GR}_{20}$, associates with proteasomes in this assay and increasing the amounts of proteasomes leads to more pulldown of $\mathrm{PR}_{20}$ (Fig. $6 \mathrm{~A}$ ). In light of this observation, we hypothesized that $\mathrm{PR}_{20}$ directly inhibits proteasomal substrate degradation.

To investigate the mechanism of action of $\mathrm{PR}_{20}$ on the proteasome, we turned to an in vitro system with predefined components. Incubation of purified proteasomes with a test substrate (Ub-Sic1) leads to time- and ATPdependent degradation of Sic1 (Verma et al., 2001). Here, we preincubated proteasomes with $\mathrm{PR}_{20}$ at various molar and subsequently followed the time-dependent degradation of Ub-Sic1 or $\mathrm{PR}_{20}$.

Ub-Sic1 or $\mathrm{PR}_{20}$ levels were determined at 0,5 , and 15 min after exposure to purified 26S proteasomes (Fig. $6 B--D)$. In these experiments, we see a time-dependent loss of Ub-Sic1 and when $\mathrm{PR}_{20}$ is added to these reactions. There is no change in the abundance of $\mathrm{PR}_{20}$ or the alpha 3 subunit of the proteasome over time. Thus, with or without $\mathrm{PR}_{20}$, we see specific degradation of Ub-Sic1 in this assay, but $\mathrm{PR}_{20}$ is not itself degraded by the proteasome (Fig. 6B).

In the absence of $P R_{20}$, there is progressive reduction in Ub-Sic1 abundance, and quantification of signal shows experimental group differences by ANOVA $\left(F_{(2,9)}=773.0\right.$, $p<0.001)$. Post hoc analysis reveals statistically significantly less Ub-Sic1 at the 5- and 15-min time points in comparison with the starting level $(p<0.001$ and $p<$ 0.001 ). At a molar ratio of $1: 10$ or $1: 100$ (proteasomes: $\mathrm{PR}_{20}$ ), there is also a progressive reduction in Ub-Sic1 abundance and quantification of signal shows experimental group differences by ANOVA $\left(F_{(2,9)}=679.5, p<0.001\right)$ and $F_{(2,9)}=762.6, p<0.001$, respectively). Post hoc analysis reveals statistically significantly less Ub-Sic1 at the 5-min $(p<0.01$ and $p<0.01)$ and 15-min $(p<0.01$ and $p<0.01)$ time points in comparison with the starting level.

Qualitatively it appears, however, that the progressive reduction of Ub-Sic1 is less pronounced in the presence of $\mathrm{PR}_{20}$. To quantify this, we monitored the difference between the Ub-Sic1 signal at the starting point versus the 5- or 15-min time point (e.g., $\Delta^{0-5}$ and $\Delta^{0-15}$ ). We then compared the $\Delta^{0-5}$ of the three experimental groups (e.g., in the absence of $\mathrm{PR}_{20}, 1: 10$ proteasomes: $\mathrm{PR}_{20}$ and $1: 100$ proteasomes: $\left.\mathrm{PR}_{20}\right)$ and found group differences by ANOVA $\left(F_{(2,9)}=32.42, p<0.001\right)$ (Fig. 6D). Post hoc analysis reveals statistically significant less $\Delta^{0-5}$ in the 1:10 and 1:100 experimental groups compared with the
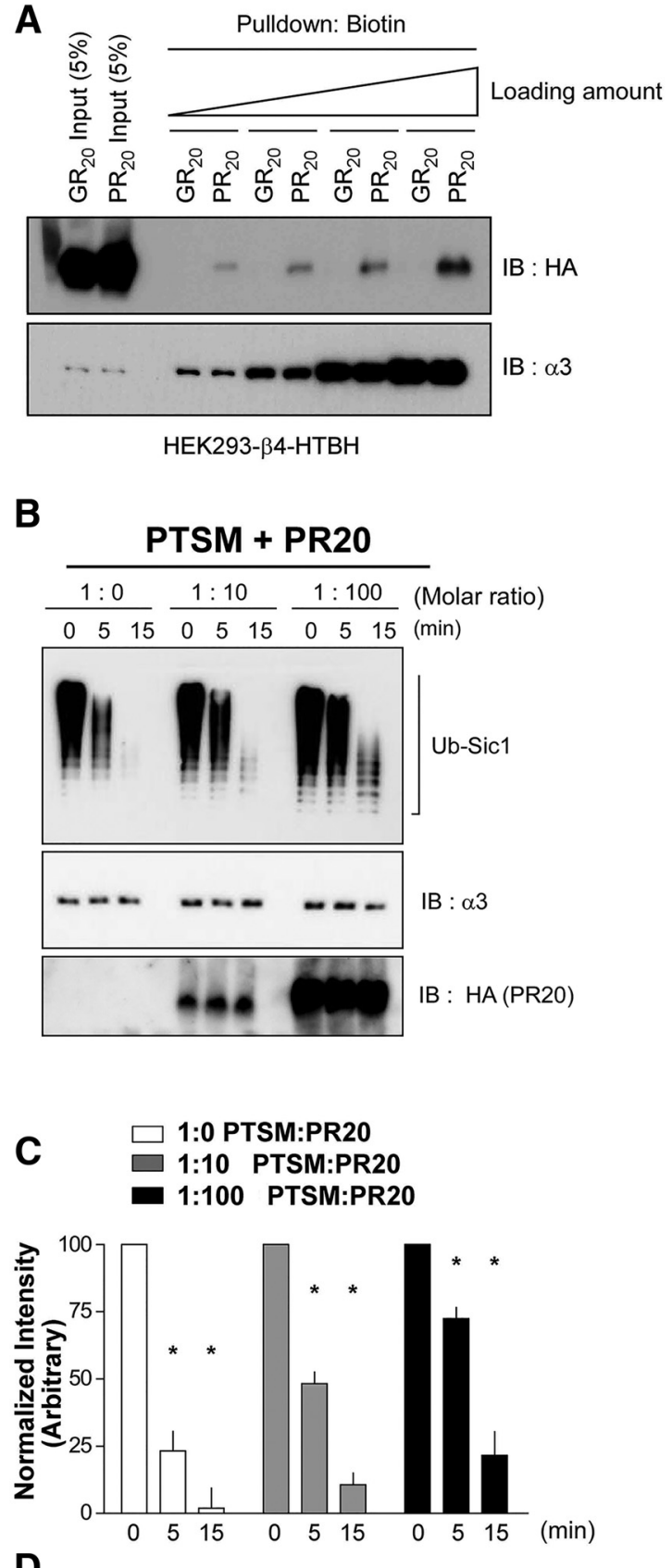

D

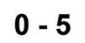

$0-15$

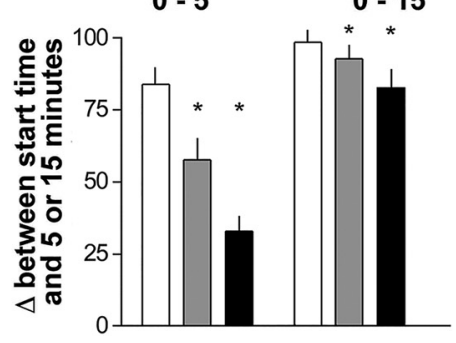

Figure 6. $\mathrm{PR}_{20}$, but not $\mathrm{GR}_{20}$ binds to proteasomes; $\mathrm{PR}_{20}$ inhibits the proteasomal degradation of a test substrate. $\boldsymbol{A}$, By pulling down human proteasomes and then immunoblotting against $\mathrm{HA}$, a direct association of $\mathrm{PR}_{20}$ (but not $\mathrm{GR}_{20}$ ) peptides to the proteasome is demonstrated. Increasing amounts of proteasome leads to more associated $\mathrm{PR}_{20}$. Proteasomes are identified 
continued

using an antibody recognizing the $\alpha 3$ subunit. $\boldsymbol{B}$, Immunoblot images of Ub-Sic1, HA tag, and $\alpha 3$ loading controls. Molar ratios represent the ratio between 26s proteasomes (PTSM) and $\mathrm{PR}_{20}$ peptides. The molar ratios of 1:0, 1:10, and 1:100 were each subject to proteasomal degradation of Ub-Sic1 for 0,5 , and 15 min. Time-dependent loss of Ub-Sic1 is noted. There is no change in the abundance of HA-tagged $\mathrm{PR}_{20}$ or the $\alpha 3$ subunit. C, Quantification of Ub-Sic1 levels normalized to loading controls for each condition. Values represent means $(n=3)$, and the error bars represent SE. $\boldsymbol{D}$, Quantification of the difference between starting level of Ub-Sic1 and Ub-Sic1 abundance at the 5and 15-min time points. $*, p<0.01$.

no $\mathrm{PR}_{20}$ group $(p<0.05$ and $p<0.05)$. Similarly, we compared the $\Delta^{0-15}$ of the three experimental groups and found group differences by ANOVA $\left(F_{(2,9)}=8.667, p=\right.$ 0.008 ) (Fig. 6D). Post hoc analysis reveals statistically significantly less $\Delta^{0-15}$ in the $1: 10$ and 1:100 experimental group compared with the no $\mathrm{PR}_{20}$ group $(p<0.05$ and $p$ $<0.05)$. Together, these observations suggest that $\mathrm{PR}_{20}$ operates at the level of the proteasome to impede the function of the UPS. This observation is consistent with the hypothesis that $\mathrm{PR}_{20}$ causes ubiquitylated substrate build-up due to impaired proteasome function.

\section{Pharmacological inhibition of the proteasome is} toxic to motor neurons, reduces flux of ubiquitylated substrates, and can be rescued by DUB inhibition

If $\mathrm{PR}_{20}$ kills motor neurons by partial inhibition of the proteasome, then partial inhibition of the proteasome by pharmacological means might: (1) be toxic to motor neurons and, critically, (2) impair proteasomal flux to a similar degree as seen with $\mathrm{PR}_{20}$. These predictions presuppose that proteasomal inhibition by $\mathrm{PR}_{20}$ and by MG132 (for example) are equivalent in terms of pharmacodynamics, pharmacokinetics, and selectivity versus nonselectivity in ubiquitylated substrate build-up. We added varying concentrations of MG132 one time to our mixed spinal cord cultures and found an $\mathrm{LD}_{50}$ of $\sim 100-150 \mathrm{nM}$ when motor neuron number was determined $5 \mathrm{~d}$ later (Fig. $7 A$ ). We then studied proteasomal flux by incubating sets of DIV14 cultures with $150 \mathrm{nM}$ MG132 or vehicle for $48 \mathrm{~h}$ and then treating half of each set with $5 \mu \mathrm{M}$ MG132 or vehicle for 4 $\mathrm{h}$ before creating cell lysates and probing for ubiquitin (as described above in Figure 4). With $n=6$ replicates in each experimental group, the permutation test found a statistically significant reduction in proteasomal flux in the 150 $\mathrm{nM}$ pretreatment group compared with the control $(p=$ 0.027 ) (Fig. 7B,C). Finally, we asked whether proteasomal activation with the USP14 DUB inhibitor IU1 (Lee et al., 2010) could protect motor neurons from MG132 toxicity. Parallel sets of dishes were treated with 150 nM MG132 (or vehicle) and $5 \mu \mathrm{M}$ IU1 (or vehicle). Counts of motor neurons $5 \mathrm{~d}$ later revealed statistically significant group differences by ANOVA $\left(F_{(8,119)}=5.924, p<0.001\right)$. The post hoc analysis revealed statistically significantly fewer motor neurons in the MG132-treated group in comparison with all other experimental groups $(p=0.001)$. No other group differences were found (Fig. 7D). Thus, pharmacological inhibition of the proteasome that achieves a reduc-
A
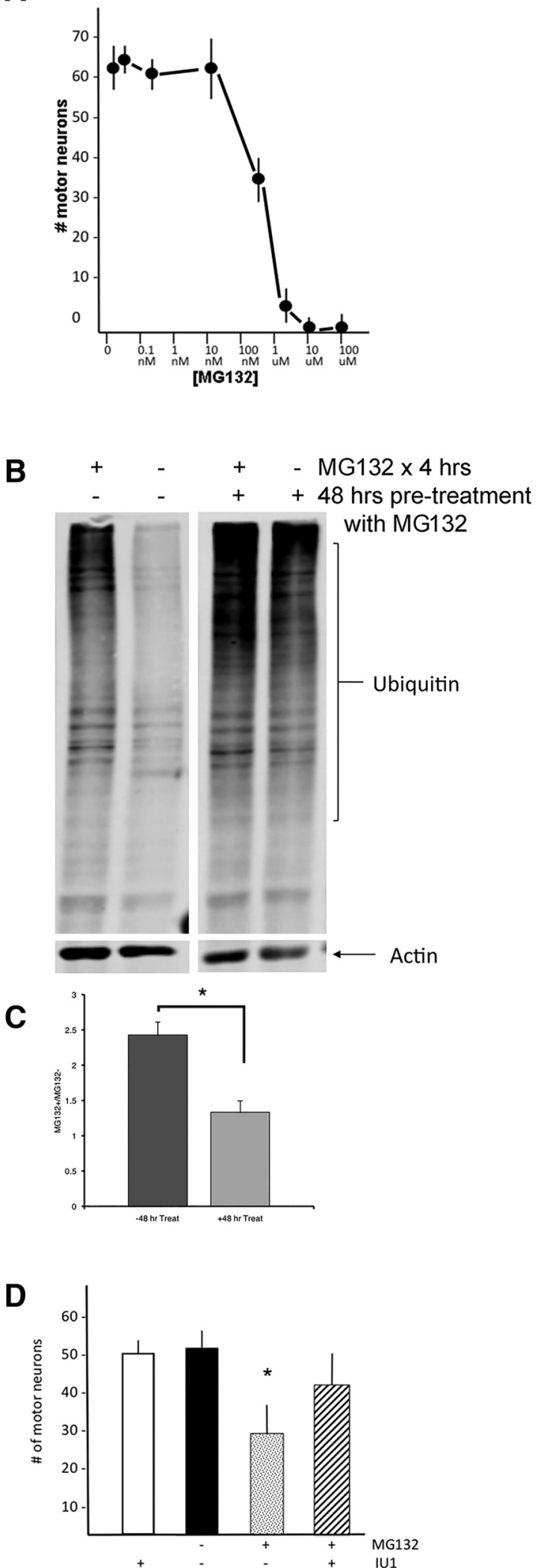

Figure 7. MG132 is toxic to motor neurons, inhibits flux through the proteasome, and cell death is rescued by the DUB inhibitor IU1. MG132 was applied one time at varying concentrations to mixed spinal cord cultures and $5 \mathrm{~d}$ later processed for immuno- 


\section{continued}

cytochemical quantification of motor neurons. $\boldsymbol{A}$, The doseresponse curve shows that MG132 kills motor neurons with an LD50 of $\sim 100-150 \mathrm{nM}$. B, Mixed spinal cord cultures were exposed to $150 \mathrm{nM}$ MG132 or vehicle for $48 \mathrm{~h}$, and the parallel groups of cultures were exposed to $5 \mu \mathrm{M}$ MG132 or vehicle for $4 \mathrm{~h}$. Cell lysates were prepared and blotted for total ubiquitin levels. The difference of the ubiquitin immunoreactivity in the cultures treated with $5 \mu \mathrm{M}$ or vehicle reports the flux of substrates through the UPS over $4 \mathrm{~h}$. Representative blots are shown. $\boldsymbol{C}$, Quantification of the data from the flux assay and statistical analysis by the permutation tests reveals a statistically significant inhibition of flux through the UPS in cultures treated with $150 \mathrm{nM}$ for $48 \mathrm{~h}(p=0.027)$. $\boldsymbol{D}$, Number of motor neuron in mixed spinal cord cultures after exposure of 150 nM MG132 or vehicle and $5 \mu \mathrm{M}$ IU1 or vehicle. MG132 leads to a statistically significant reduction in motor neuron number, and this is reversed by IU1 treatment. IU1 alone is not toxic.

tion influx equivalent to $\mathrm{PR}_{20}$ evokes motor neuron death. This observation supports the view that the toxic activity of $\mathrm{PR}_{20}$ could be mediated by proteasomal inhibition; a notion reinforced by the observation that stimulation of the proteasome protects against this level of proteasomal flux inhibition.

\section{Induction of the proteasome rescues neuronal survival in the presence of $\mathbf{P R}_{\mathbf{2 0}}$}

Finally, we asked whether IU1 protects against $\mathrm{PR}_{20^{-}}$ induced motor neuron death. We applied $\mathrm{PR}_{20}$ (or vehicle) and IU1 (or vehicle) to cultures and quantified the number of motor neurons alive after $5 \mathrm{~d}$ of treatment with each condition (Fig. 8). Statistically significant group differ-

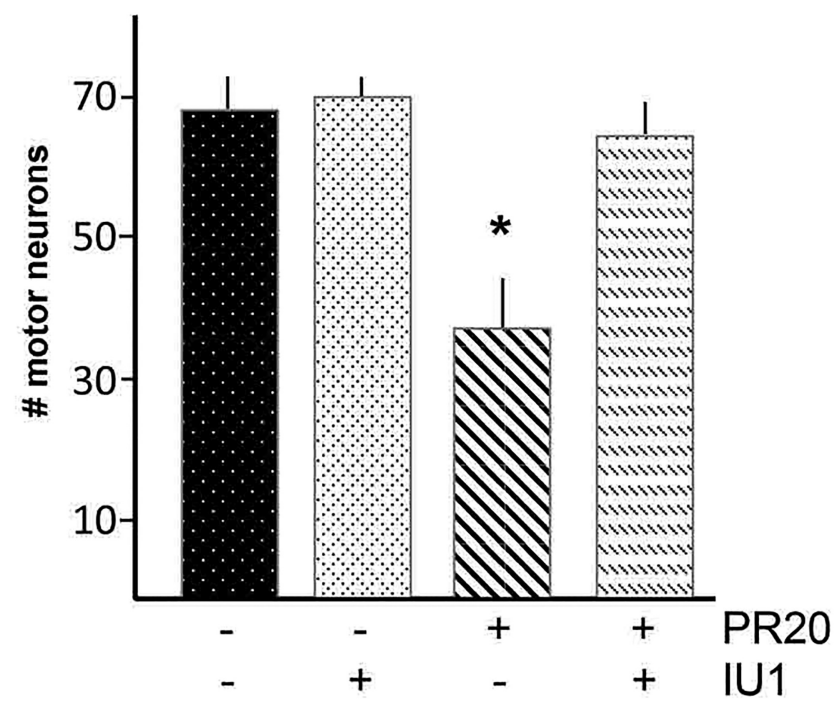

Figure 8. $\mathrm{PR}_{20}$-evoked motor neuron death is prevented by the proteasome activator, IU1. Mixed spinal cord cultures were exposed to $\mathrm{PR}_{20}$ or vehicle and then dosed with IU1 or vehicle. Motor neuron number was determined $5 \mathrm{~d}$ later. In the absence of $\mathrm{PR}_{20}$, IU1 did not affect motor neuron survival. $\mathrm{PR}_{20}$ treatment leads to approximately $50 \%$ loss of motor neurons and IU1 application prevents this effect. n.s., not significant; $*, p<0.05$. ences were found by ANOVA $\left(F_{(8,132)}=7.408, p<0.001\right)$. The post hoc analysis indicated that a statistically significant decrease in motor neuron survival occurs in the presence of $\mathrm{PR}_{20}$ and this is rescued to control levels upon treatment with IU1 $(p<0.05)$. IU1 did not influence the survival of vehicle-treated cells. This suggests that the $\mathrm{PR}_{20}$-mediated proteasomal degradation dysfunction plays a role in the lethality that the dipeptide imparts on cells.

\section{Discussion}

The mechanism by which C9ORF72 HRE mutations cause ALS/frontotemporal dementia (FTD) (Renton et al., 2011 ) is an active area of inquiry. Evidence exists for both a toxic RNA gain-of-function and for the production of toxic DPR proteins (Haeusler et al., 2014; Mizielinska et al., 2014). In an effort to distinguish between the contributions of RNA versus that of DPR proteins, we studied the effects of synthetic dipeptides on mixed cultures. We find that $\mathrm{PR}_{20}$ is taken up by neurons and astrocytes and disrupts both the UPS and the autophagic protein degradation pathways. $\mathrm{GR}_{20}$, however, did not have an effect on the UPS. $\mathrm{PR}_{20}$ has a direct inhibitory effect upon the proteasome when tested in vitro. It is likely that these effects of $\mathrm{PR}_{20}$ are pathophysiological since pharmacological stimulation of the proteasome promotes motor neuron survival in the presence of $P_{20}$. The effects of $\mathrm{PR}_{20}$ appear molecularly distinct from mTDP43- or mSOD-mediated toxicity (Betz and Hall, 2013; Saxena et al., 2013; Perera et al., 2014; Kong and Xu, 1998). Our results suggest a specific mechanism by which proline/ arginine DPR proteins are injurious to motor neurons. Since DPR peptides are seen in human autopsy tissues (Ash et al., 2013; Mori et al., 2013), our in vitro observations have implications for human disease.

Among the technical considerations inherent in all disease models, we feel that three merit special discussion. First, many of our experiments are performed after adding $\mathrm{PR}_{20}$ to the culture media, achieving an extracellular concentration of $2 \mu \mathrm{M}$. What intracellular concentration of $\mathrm{PR}_{20}$ does this translate into, does it vary over time and/or by cell-type, and most importantly, how do these values compare to the concentration of cellular DPR proteins generated in other experimental platforms? There are no good data on these difficult questions. It is noteworthy that many investigators have deployed the CMV or CAGG promoters to drive high DPR protein expression from an engineered cDNA (Wen et al., 2014; Zhang et al., 2014; Yamakawa et al., 2015). Unfortunately, we lack the quantitative data on the cellular concentration of RAN peptides in these models that could form the basis of comparison with our results. Second, when using purified proteasomes and a ubiquitylated test substrate in vitro (e.g., Ub-Sic1) to determine proteasomal degradation rate, is the $\mathrm{PR}_{20}$-dependent inhibition of the proteasome reporting a physiological event? This is a valid concern, since we only see the $P R_{20}$ effect when the molar ratio of $P R_{20}$ to proteasomes is 10:1 or greater. The protein concentration in our in vitro reaction is $20 \mathrm{nM}$, and it is not possible to substantially increase the concentration because the 
proteins no longer remain soluble. On the other hand, estimates of protein concentrations in cells are about 0.25 $\mathrm{g} / \mathrm{ml}$ [which for $100-\mathrm{kDa}$ proteins is roughly equivalent to $5 \mathrm{mM}$ (Milo, 2013)], $\sim 5$ orders of magnitude greater than that which can be achieved in vitro. The biology of RAN peptides and proteasomes in the crowded environment of cells can, at best, be approximated by in vitro assays, although synthetic $\mathrm{PR}_{20}$ and purified human proteasomes directly interact with each other. Whether the 10:1 ratio is truly reporting on events occurring in vitro will ultimately depend on its predictive value. In light of all of the data we have assembled, we think a reasonable case can be made that the Ub-Sic1/proteasome/PR ${ }_{20}$ observations are valid and relevant. Third, when DPR proteins are expressed from a cDNA, 36 repeat products (Mizielinska et al., 2014; Tran et al., 2015), 42 repeat products (Wen et al., 2014), 50 repeat products (Zhang et al., 2014), 66 repeat products (Kramer et al., 2016), and 100 repeat products (Yamakawa et al., 2015) are toxic. The extent to which cognate cDNAs are translated to generate the intended full-length product is unclear. In addition, the length of DPRs that are benign and the length beyond which toxicity is detectable remains murky. The selection of 20 repeats of PR or GR in our study was based on the observations of others that this length of DPR can be toxic (Kwon et al., 2014; Kanekura et al., 2016). DPRs as short as 6 repeats (such as $\mathrm{GR}_{6}$ and $\mathrm{GA}_{6}$ ) can be toxic to neurons; we do not know whether $\mathrm{PR}_{6}$ is toxic and if so, whether this involves the proteasome (Flores et al., 2016). Future studies should investigate these issues as well as determine the prevalence of DPRs of specific lengths in human cells with HRE C9ORF72.

In an attempt to distinguish the effects of toxic mRNA species from those of DPR proteins, many research groups have taken advantage of the degeneracy in the genetic code to create DPR proteins in the absence of GGGGCC repeats. Whether the cognate mRNA by itself is truly nontoxic remains, in our opinion, an open question. G-C-rich RNAs can adopt a variety of secondary structures even without long, uninterrupted stretches of GGGGCC that could attract and sequester RNA-binding proteins. We believe that studies in which cognate RNA is translated to create DPR proteins do not exclude the possibility of RNA toxicity and thus should be interpreted with caution. Only a few groups have studied the effects of synthetic DPR peptides (unambiguously excluding the contribution of mRNA toxicity in models of C9ORF72 HRE toxicity) (Kwon et al., 2014; Chang et al., 2016; Kanekura et al., 2016), and only one studied primary neurons (Flores et al., 2016).

Notwithstanding the above concerns using translation of non-GGGGCC constructs to generate diamino acid peptide, many groups have investigated the toxicities of various DPR proteins. Wen et al. (2014) showed that $\mathrm{PR}_{\mathrm{n}}$ is toxic in primary cortical and motor neuron cultures, and Mizielinska et al. (2014) and Wen et al. (2014) found that $\mathrm{PR}_{n}$ and $\mathrm{GR}_{n}$, but not $P A_{n}$ and $G A_{n}$, are toxic in a fly model. In primary neuron cultures, $\mathrm{GA}_{\mathrm{n}}$ and $\mathrm{GR}_{\mathrm{n}}$ are toxic (May et al., 2014; Zhang et al., 2014; Flores et al., 2016), and this can be associated with ER stress and cytoplas- mic/nuclear inclusions. Joviči et al. (2015) also showed $\mathrm{PR}_{\mathrm{n}}, \mathrm{PA}_{\mathrm{n}}$, and $\mathrm{GR}_{\mathrm{n}}$ are toxic in a yeast model. Recently described mouse work adds further interpretive difficulties. O'Rourke et al. (2015) showed that $\mathrm{GA}_{n}$ and $\mathrm{GP}_{\mathrm{n}}$ dipeptides accumulated in a bacterial artificial chromosome transgenic mouse model but were not associated with phenotypic changes to mouse behavior or neurodegeneration. On the other hand, Yamakawa et al. (2015) found $\mathrm{GA}_{\mathrm{n}}$ linked behavioral deficits using in utero electroporation in mice to express the dipeptides in the cerebral cortex. In sum, while there is no question that DPR proteins are present in patients and in various disease models, precisely which species are toxic (or the extent to which they are toxic) remains contentious.

We, and others (Kwon et al., 2014), have found that $\mathrm{PR}_{20}$ accumulates in the nucleus, raising the interesting prospect that inhibition of nuclear proteasomes underlies the pathophysiology. Protein quality control $(P Q C)$ pathways manage misfolded proteins within distinct subcellular compartments (Shibata and Morimoto, 2014). There is a rich literature about PQC in the ER and cytoplasm, but less is known about PQC in the nucleus. The UPS is the main mechanism for protein degradation in the nucleus (Jones and Gardner, 2016; Gallagher et al., 2014; Shibata and Morimoto, 2014) and the nucleus harbors the majority of cellular proteasomes (Wójcik and DeMartino, 2003; although see Dang et al., 2016). In yeast, the San1 ubiquitin ligase targets misfolded nuclear proteins for proteasomal degradation (Gardner et al., 2005; Rosenbaum et al., 2011). Other ubiquitin ligases implicated in nuclear PQC include Ubr1, Doa10, and Asi, others are likely to exist (Jones and Gardner, 2016). In addition to targeting misfolded nuclear proteins, some cytosolic proteins (i.e., polyQ-expanded proteins) are imported into the nucleus for degradation (Park et al., 2013). The features of damaged cytosolic proteins that identify them for nuclear import and disposal by the nuclear PQC pathway are unknown. $\mathrm{PR}_{20}$ inhibition of nuclear proteasomes could have broad effects not only on the integrity of the nuclear proteome but also on interconnected PQC pathways in other subcellular domains.

In various disease model platforms, HRE RNA foci and DPR protein puncta have been demonstrated. Our understanding of how these entities are linked to cell dysfunction and death is inchoate. Additionally, defects in nucleocytoplasmic shuttling, ER stress, proteasomal dysfunction, and nucleolar stress have also been described in various models. However, a detailed connection of these processes gone awry and disease pathogenesis is not well understood (Kwon et al., 2014; Wen et al., 2014; Freibaum et al., 2015; Joviči et al., 2015; Yamakawa et al., 2015; Zhang et al., 2015; Zhang et al., 2016).

Here, we show that $\mathrm{PR}_{20}$ dipeptides kill motor neurons and lead to a time-dependent build-up of ubiquitylated substrates, an effect we ascribed to an impairment of both the UPS and autophagy pathways. $\mathrm{PR}_{20}$ physically associated with the proteasome and we suggest that this interaction underlies the functional impairment of the UPS. That another RAN translation product, $\mathrm{GR}_{20}$, is neither toxic to motor neurons nor leads to impairment in 
UPS flux, highlights the specificity of the proposed molecular mechanism for $\mathrm{PR}_{20}$ toxicity. To understand why the accumulation of ubiquitylated substrates is toxic, it will be important to determine which ubiquitylated substrates accumulate in the presence of $\mathrm{PR}_{20}$. Two broad possibilities exist: (1) $\mathrm{PR}_{20}$ may nonspecifically inhibit the degradation of ubiquitylated substrates, and this could be toxic owing to the accumulation of damaged $/ \mathrm{misfolded}$ proteins; or (2) $\mathrm{PR}_{20}$ may inhibit the degradation of a specific subset of ubiquitylated substrates, and this could be toxic owing to the disruption of a select cell biological process. Resolving the contributions of these alternative possibilities may provide mechanistic insight into the pathophysiology.

\section{References}

Aiken CT, Kaake RM, Wang X, Huang L (2011) Oxidative stressmediated regulation of proteasome complexes. Mol Cell Proteomics 10:R110.006924. CrossRef

Al-Sarraj S, King A, Troakes C, Smith B, Maekawa S, Bodi I, Rogelj B, Al-Chalabi A, Hortobágyi T, Shaw CE (2011) p62 positive, TDP-43 negative, neuronal cytoplasmic and intranuclear inclusions in the cerebellum and hippocampus define the pathology of C9ORF72-linked FTLD and MND/ALS. Acta Neuropathol 122:691702. CrossRef

Arrasate M, Mitra S, Schweitzer ES, Segal MR, Finkbeiner S (2004) Inclusion body formation reduces levels of mutant huntingtin and the risk of neuronal death. Nature 431:805-810. CrossRef

Ash PEA, Bieniek KF, Gendron TF, Caulfield T, Lin WL, DeJesusHernandez M, ... Petrucelli L (2013) Unconventional translation of C9ORF72 GGGGCC expansion generates insoluble polypeptides specific to c9FTD/ALS. Neuron 77:639-646. CrossRef

Baldin V, Militello M, Thomas Y, Doucet C, Fic W, Boireau S, JarielEncontre I, Piechaczyk M, Bertrand E, Tazi J, Coux O (2008) A novel role for PA28 $\gamma$-proteasome in nuclear speckle organization and SR protein trafficking. Mol Biol Cell 19:1706-1716. CrossRef

Bao W, Gu Y, Ta L, Wang K, Xu Z (2016) Induction of autophagy by the MG132 proteasome inhibitor is associated with endoplasmic reticulum stress in MCF7 cells. Mol Med Rep 13:796-804. CrossRef

Barber SC, Mead RJ, Shaw PJ (2006) Oxidative stress in ALS: a mechanism of neurodegeneration and a therapeutic target. Biochim Biophys Acta 1762:1051-1067. CrossRef Medline

Barmada SJ, Serio A, Arjun A, Bilican B, Daub A, Ando DM, Tsvetkov A, Pleiss M, Li X, Peisach D, Shaw C, Chandran S, Finkbeiner S (2014) Autophagy induction enhances TDP43 turnover and survival in neuronal ALS models. Nat Chem Biol 10:677-685. CrossRef Medline

Bence NF, Sampat RM, Kopito RR (2001) Impairment of the ubiquitin-proteasome system by protein aggregation. Science 292:1552-1555. CrossRef

Betz C, Hall MN (2013) Where is mTOR and what is it doing there? J Cell Biol 203:563-574. CrossRef Medline

Boeynaems S, Bogaert E, Michiels E, Gijselinck I, Sieben A, Joviči A, De Baets G, Scheveneels W, Steyaert J, Cuijt I, Verstrepen KJ, Callaerts P, Rousseau F, Schymkowitz J, Cruts M, Van Broeckhoven C, Van Damme P, Gitler AD, Robberecht W, Van Den Bosch $L$ (2016) Drosophila screen connects nuclear transport genes to DPR pathology in c9ALS/FTD. Sci Rep 6:20877. CrossRef Medline

Cheng Y, Ren X, Hait WN, Yang JM (2013) Therapeutic targeting of autophagy in disease: biology and pharmacology. Pharmacol Rev 65:1162-1197. CrossRef

Chang YJ, Jeng US, Chiang YL, Hwang IS, Chen YR (2016) Glycinealanine dipeptide repeat from C9ORF72 hexanucleotide expansions forms toxic amyloids possessing cell-to-cell transmission property. J Biol Chem 291:4903-4911. CrossRef
Conlon EG, Lu L, Sharma A, Yamazaki T, Tang T, Shneider NA, Manley JL (2016) The C9ORF72 GGGGCC expansion forms RNA $\mathrm{G}$-quadruplex inclusions and sequesters hnRNP H to disrupt splicing in ALS brains. eLife 5:345. CrossRef

Choi WH, de Poot SAH, Lee JH, Kim JH, Han DH, Kim YK, Finley D, Lee MJ (2016) Open-gate mutants of the mammalian proteasome show enhanced ubiquitin-conjugate degradation. Nat Commun 7:10963. CrossRef

Chudakov DM, Lukyanov S, Lukyanov KA (2007) Tracking intracellular protein movements using photoswitchable fluorescent proteins PS-CFP2 and Dendra2. Nat Protoc 2:2024-2032. CrossRef

Dang FW, Chen L, Madura K (2016) Catalytically active proteasomes function predominantly in the cytosol. J Biol Chem 291:1876518777. CrossRef

DeJesus-Hernandez M, Mackenzie IR, Boeve BF, Boxer AL, Baker M, Rutherford NJ, Nicholson AM, Finch NA, Flynn H, Adamson J, Kouri N, Wojtas A, Sengdy P, Hsiung GY, Karydas A, Seeley WW, Josephs KA, Coppola G, Geschwind DH, Wszolek ZK, Feldman H, et al. (2011) Expanded GGGGCC hexanucleotide repeat in noncoding region of C9ORF72 causes chromosome 9p-linked FTD and ALS. Neuron 72:245-256. CrossRef

Ding WX, Ni HM, Gao W, Yoshimori T, Stolz DB, Ron D, Yin XM (2007) Linking of autophagy to ubiquitin-proteasome system is important for the regulation of endoplasmic reticulum stress and cell viability. Am J Pathol 171:513-524. CrossRef

Fingar DC, Richardson CJ, Tee AR, Cheatham L, Tsou C, Blenis J (2004) mTOR controls cell cycle progression through its cell growth effectors S6K1 and 4E-BP1/eukaryotic translation initiation factor 4E. Mol Cell Biol 24:200-216. CrossRef

Flores BN, Dulchaversusky ME, Krans A, Sawaya MR, Paulson HL, Todd PK, et al. (2016) Distinct C9orf72-associated dipeptide repeat structures correlate with neuronal toxicity. PLoS One 11: e0165084. CrossRef

Freibaum BD, Lu Y, Lopez-Gonzalez R, Kim NC, Almeida S, Lee KH, Badders N, Valentine M, Miller BL, Wong PC, Petrucelli L, Kim H, Gao FB, Taylor JP (2015) GGGGCC repeat expansion in C9ORF72 compromises nucleocytoplasmic transport. Nature 525:129-133. CrossRef

Gallagher PS, Oeser ML, Abraham AC, Kaganovich D, Gardner RG (2014) Cellular maintenance of nuclear protein homeostasis. Cell Mol Life Sci 71:1865-1879. CrossRef Medline

Gardner RG, Nelson ZW, Gottschling DE (2005) Degradationmediated protein quality control in the nucleus. Cell 120:803-815. CrossRef Medline

Gitler AD, Tsuiji H (2016) There has been an awakening: emerging mechanisms of C9ORF72 mutations in FTD/ALS. Brain Res 1647: 19-29. CrossRef

Glick D, Barth S, Macleod KF (2010) Autophagy: cellular and molecular mechanisms. J Pathol 221:3-12. CrossRef Medline

Glickman MH, Ciechanover A (2002) The ubiquitin-proteasome proteolytic pathway: destruction for the sake of construction. Physiol Rev 82:373-428. CrossRef

Goldberg AL (2012) Development of proteasome inhibitors as research tools and cancer drugs. J Cell Biol 199:583-588. CrossRef Medline

Gubbens J, Ruijter E, de Fays LEV, Damen JMA, de Kruijff B, Slijper M, Rijkers DT, Liskamp RM, de Kroon Al (2009) Photocrosslinking and click chemistry enable the specific detection of proteins interacting with phospholipids at the membrane interface. Chem Biol 16:3-14. CrossRef

Haeusler AR, Donnelly CJ, Periz G, Simko EAJ, Shaw PG, Kim MS Maragakis NJ, Troncoso JC, Pandey A, Sattler R, Rothstein JD, Wang J (2014) C9ORF72 nucleotide repeat structures initiate molecular cascades of disease. Nature 507:195-200. CrossRef

Jones RD, Gardner RG (2016) Protein quality control in the nucleus. Curr Opin Cell Biol 40:81-89. CrossRef Medline

Joviči A, Mertens J, Boeynaems S, Bogaert E, Chai N, Yamada SB, Paul JW 3rd, Sun S, Herdy JR, Bieri G, Kramer NJ, Gage FH, Van Den Bosch L, Robberecht W, Gitler AD (2015) Modifiers of C9ORF72 dipeptide repeat toxicity connect nucleocytoplasmic 
transport defects to FTD/ALS. Nat Neurosci 18:1226-1229. CrossRef

Joyce PI, Fratta P, Fisher EMC, Acevedo-Arozena A (2011) SOD1 and TDP-43 animal models of amyotrophic lateral sclerosis: recent advances in understanding disease toward the development of clinical treatments. Mamm Genome 22:420-448. CrossRef

Kabashi E, Agar JN, Strong MJ, Durham HD (2012) Impaired proteasome function in sporadic amyotrophic lateral sclerosis. Amyotroph Lateral Scler 13:367-371. CrossRef

Kanekura K, Yagi T, Cammack AJ, Mahadevan J, Kuroda M, Harms MB, Miller TM, Urano F (2016) Poly-dipeptides encoded by the C9ORF72 repeats block global protein translation. Hum Mol Genet 25:1803-1813. CrossRef

Kaufman RJ (1999) Stress signaling from the lumen of the endoplasmic reticulum: coordination of gene transcriptional and translational controls. Genes Dev 13:1211-1233. CrossRef

Kiernan MC, Vucic S, Cheah BC, Turner MR, Eisen A, Hardiman O, Burrell JR, Zoing MC (2011) Amyotrophic lateral sclerosis. Lancet 377:942-955. CrossRef Medline

Klionsky DJ, Abdalla FC, Abeliovich H, Abraham RT, AcevedoArozena A, Adeli K, Agholme L, Agnello M, Agostinis P, AguirreGhiso JA, Ahn HJ, Ait-Mohamed O, Ait-Si-Ali S, Akematsu T, Akira $\mathrm{S}$, Al-Younes HM, Al-Zeer MA, Albert ML, Albin RL, AlegreAbarrategui J, et al. (2012) Guidelines for the use and interpretation of assays for monitoring autophagy. Autophagy 8:445-544. Medline

Klionsky DJ, Abdelmohsen K, Abe A, Abedin MJ, Abeliovich $\mathrm{H}$, Acevedo Arozena A, Adachi $\mathrm{H}$, Adams CM, Adams PD, Adeli K, Adhihetty PJ, Adler SG, Agam G, Agarwal R, Aghi MK, Agnello M, Agostinis P, Aguilar PV, Aguirre-Ghiso J, Airoldi EM, et al. (2016) Guidelines for the use and interpretation of assays for monitoring autophagy (3rd edition). Autophagy 12:1-222. CrossRef Medline

Koga H, Martinez-Vicente M, Macian F, Verkhusha VV, Cuervo AM (2011) A photoconvertible fluorescent reporter to track chaperonemediated autophagy. Nat Commun 2:386. CrossRef

Kong J, Xu Z (1998) Massive mitochondrial degeneration in motor neurons triggers the onset of amyotrophic lateral sclerosis in mice expressing a mutant SOD1. J Neurosci 18:3241-3250.

Kramer NJ, Carlomagno Y, Zhang YJ, Almeida S, Cook CN, Gendron TF, et al. (2016) Spt4 selectively regulates the expression of C9ORF72 sense and antisense mutant transcripts. Science 353: 708-712. CrossRef Medline

Kwon I, Xiang S, Kato M, Wu L, Theodoropoulos P, Wang T, Kim J, Yun J, Xie Y, McKnight SL (2014) Poly-dipeptides encoded by the C9ORF72 repeats bind nucleoli, impede RNA biogenesis, and kill cells. Science 345:1139-1145. CrossRef Medline

Lan D, Wang W, Zhuang J, Zhao Z (2015) Proteasome inhibitorinduced autophagy in PC12 cells overexpressing A53T mutant $\alpha$-synuclein. Mol Med Rep 11:1655-1660. CrossRef

Lecker SH, Goldberg AL, Mitch WE (2006) Protein degradation by the ubiquitin-proteasome pathway in normal and disease states. J Am Soc Nephrol 17:1807-1819. CrossRef

Lee BH, Lee MJ, Park S, Oh DC, Elsasser S, Chen PC, Gartner C, Dimova N, Hanna J, Gygi SP, Wilson SM, King RW, Finley D (2010) Enhancement of proteasome activity by a small-molecule inhibitor of USP14. Nature 467:179-184. CrossRef Medline

Lee KH, Zhang P, Kim HJ, Mitrea DM, Sarkar M, Freibaum BD, Cika J, Coughlin M, Messing J, Molliex A, Maxwell BA, Kim NC, Temirov J, Moore J, Kolaitis RM, Shaw TI, Bai B, Peng J, Kriwacki RW, Taylor JP (2016) C9ORF72 dipeptide repeats impair the assembly, dynamics, and function of membrane-less organelles. Cell 167: 774-788.e17. CrossRef Medline

Li J, McCullough LD (2010) Effects of AMP-activated protein kinase in cerebral ischemia. J Cereb Blood Flow Metab 30:480-492. CrossRef Medline

Lilienbaum A (2013) Relationship between the proteasomal system and autophagy. Int J Biochem Mol Biol 4:1-26. Medline

Lim MA, Selak MA, Xiang Z, Krainc D, Neve RL, Kraemer BC, Watts JL, Kalb RG (2012) Reduced activity of AMP-activated protein kinase protects against genetic models of motor neuron disease. $J$ Neurosci 32:1123-1141. CrossRef

Lin Y, Mori E, Kato M, Xiang S, Wu L, Kwon I, McKnight SL (2016) Toxic PR poly-dipeptides encoded by the C9ORF72 repeat expansion target LC domain polymers. Cell 167:789-802.e12. CrossRef Medline

Ling SC, Polymenidou M, Cleveland DW (2013) Converging mechanisms in ALS and FTD: disrupted RNA and protein homeostasis. Neuron 79:416-438. CrossRef Medline

Loos B, du Toit A, Hofmeyr JHS (2014) Defining and measuring autophagosome flux-concept and reality. Autophagy 10:20872096. CrossRef Medline

May S, Hornburg D, Schludi MH, Arzberger T, Rentzsch K, Schwenk BM, Grässer FA, Mori K, Kremmer E, Banzhaf-Strathmann J, Mann M, Meissner F, Edbauer D (2014) C9ORF72 FTLD/ALS-associated Gly-Ala dipeptide repeat proteins cause neuronal toxicity and Unc119 sequestration. Acta Neuropathol 128:485-503. CrossRef Medline

Meyer AJ, Brach T, Marty L, Kreye S, Rouhier N, Jacquot JP, Hell R (2007) Redox-sensitive GFP in Arabidopsis thaliana is a quantitative biosensor for the redox potential of the cellular glutathione redox buffer. Plant J 52:973-986. CrossRef

Milo $R$ (2013) What is the total number of protein molecules per cell volume? A call to rethink some published values. BioEssays 35: 1050-1055. CrossRef

Mizielinska S, Grönke S, Niccoli T, Ridler CE, Clayton EL, Devoy A, Moens T, Norona FE, Woollacott IO, Pietrzyk J, Cleverley K, Nicoll AJ, Pickering-Brown S, Dols J, Cabecinha M, Hendrich O, Fratta P, Fisher EM, Partridge L, Isaacs AM (2014) C9ORF72 repeat expansions cause neurodegeneration in Drosophila through argininerich proteins. Science 345:1192-1194. CrossRef

Mizushima N, Yoshimori T, Levine B (2010) Methods in mammalian autophagy research. Cell 140:313-326. CrossRef Medline

Mojsilovic-Petrovic J, Jeong GB, Crocker A, Arneja A, David S, Russell D, Kalb RG (2006) Protecting motor neurons from toxic insult by antagonism of adenosine A2a and Trk receptors. J Neurosci 26:9250-9263. CrossRef

Mori K, Weng SM, Arzberger T, May S, Rentzsch K, Kremmer E, Schmid B, Kretzschmar HA, Cruts M, Van Broeckhoven C, Haass C, Edbauer D (2013) The C9ORF72 GGGGCC repeat is translated into aggregating dipeptide-repeat proteins in FTLD/ALS. Science 339:1335-1338. CrossRef Medline

O'Rourke JG, Bogdanik L, Muhammad AKMG, Gendron TF, Kim KJ, Austin A, Cady J, Liu EY, Zarrow J, Grant S, Ho R, Bell S, Carmona S, Simpkinson M, Lall D, Wu K, Daughrity L, Dickson DW, Harms $\mathrm{MB}$, Petrucelli L, et al. (2015) C9ORF72 BAC transgenic mice display typical pathologic features of ALS/FTD. Neuron 88:892901. CrossRef

Park SH, Kukushkin Y, Gupta R, Chen T, Konagai A, Hipp MS, Hayer-Hartl M, Hartl FU (2013) PolyQ proteins interfere with nuclear degradation of cytosolic proteins by sequestering the Sis1p chaperone. Cell 154:134-145. CrossRef Medline

Pearson CE (2011) Repeat associated non-ATG translation initiation: one DNA, two transcripts, seven reading frames, potentially nine toxic entities! PLoS Genet 7:e1002018. CrossRef

Perera ND, Sheean RK, Scott JW, Kemp BE, Horne MK, Turner BJ (2014) Mutant TDP-43 deregulates AMPK activation by PP2A in ALS models. PLoS One 9:e90449. CrossRef Medline

Renton AE, Majounie E, Waite A, Simón-Sánchez J, Rollinson S, Gibbs JR, Schymick JC, Laaksovirta H, van Swieten JC, Myllykangas L, Kalimo H, Paetau A, Abramzon Y, Remes AM, Kaganovich A, Scholz SW, Duckworth J, Ding J, Harmer DW, Hernandez DG, et al. (2011) A hexanucleotide repeat expansion in C9ORF72 is the cause of chromosome 9p21-linked ALS-FTD. Neuron 72:257-268. CrossRef

Rivett AJ, Palmer A, Knecht E (1992) Electron microscopic localization of the multicatalytic proteinase complex in rat liver and in cultured cells. J Histochem Cytochem 40:1165-1172. CrossRef

Rosen DR, Siddique T, Patterson D, Figlewicz DA, Sapp P, Hentati A, Donaldson D, Goto J, O'Regan JP, Deng HX, et al. (1993) Muta- 
tions in $\mathrm{Cu} / \mathrm{Zn}$ superoxide dismutase gene are associated with familial amyotrophic lateral sclerosis. Nature 362:59-62. CrossRef Rosenbaum JC, Fredrickson EK, Oeser ML, Garrett-Engele CM, Locke MN, Richardson LA, Nelson ZW, Hetrick ED, Milac TI, Gottschling DE, Gardner RG (2011) Disorder targets misorder in nuclear quality control degradation: a disordered ubiquitin ligase directly recognizes its misfolded substrates. Mol Cell 41:93-106. CrossRef

Rowland LP, Shneider NA (2001) Amyotrophic lateral sclerosis. N Engl J Med 344:1688-1700. CrossRef Medline

Rutherford NJ, Heckman MG, DeJesus-Hernandez M, Baker MC, Soto-Ortolaza Al, Rayaprolu S, Stewart H, Finger E, Volkening K, Seeley WW, Hatanpaa KJ, Lomen-Hoerth C, Kertesz A, Bigio EH, Lippa C, Knopman DS, Kretzschmar HA, Neumann M, Caselli RJ, White CL 3rd, et al. (2012) Length of normal alleles of C9ORF72 GGGGCC repeat do not influence disease phenotype. Neurobiol Aging 33:2950.e5-2950.e7. CrossRef

Saxena S, Roselli F, Singh K, Leptien K, Julien JP, Gros-Louis F, Caroni P (2013) Neuroprotection through excitability and mTOR required in ALS motoneurons to delay disease and extend survival. Neuron 80:80-96. CrossRef

Shibata Y, Morimoto RI (2014) How the nucleus copes with proteotoxic stress. Curr Biol 24:R463-R474. CrossRef Medline

Tanida I, Ueno T, Kominami E (2008). LC3 and autophagy. In: Autophagosome and phagosome (Deretic V, ed), pp 77-88. Totowa, $\mathrm{NJ}$ : Humana Press. Retrieved from CrossRef

Tran H, Almeida S, Moore J, Gendron TF, Chalasani U, Lu Y, et al. (2015) Differential toxicity of nuclear RNA foci versus dipeptide repeat proteins in a Drosophila model of C9ORF72 FTD/ALS. Neuron 87:1207-1214. CrossRef

Tsvetkov AS, Arrasate M, Barmada S, Ando DM, Sharma P, Shaby BA, Finkbeiner $S$ (2013) Proteostasis of polyglutamine varies among neurons and predicts neurodegeneration. Nat Chem Biol 9:586-592. CrossRef Medline

Verma R, McDonald H, Yates JR, III, Deshaies RJ (2001) Selective degradation of ubiquitinated Sic1 by purified $26 \mathrm{~S}$ proteasome yields active $S$ phase cyclin-Cdk. Mol Cell 8:439-448. CrossRef Medline

Vilchez D, Saez I, Dillin A (2014) The role of protein clearance mechanisms in organismal ageing and age-related diseases. Nat Commun 5: 5659. Retrieved from CrossRef

Vitale A, Denecke J (1999) The endoplasmic reticulum - gateway of the secretory pathway. Plant Cell 11:615-628. CrossRef Medline

Wen X, Tan W, Westergard T, Krishnamurthy K, Markandaiah SS, Shi Y, Lin S, Shneider NA, Monaghan J, Pandey UB, Pasinelli P, Ichida JK, Trotti D (2014a) Antisense proline-arginine RAN dipeptides linked to C9ORF72-ALS/FTD form toxic nuclear aggregates that initiate in vitro and in vivo neuronal death. Neuron 84:1213-1225. CrossRef

Westergard T, Jensen BK, Wen X, Cai J, Kropf E, lacovitti L, et al. (2016) Cell-to-cell transmission of dipeptide repeat proteins linked to C9ORF72-ALS/FTD. Cell Rep 17:645-652. CrossRef Medline

Wijesekera L, Leigh PN (2009) Amyotrophic lateral sclerosis. Orphanet J Rare Dis 4:3. CrossRef

Wójcik C, DeMartino GN (2003) Intracellular localization of proteasomes. Int J Biochem Cell 35:579-589.

Yamakawa M, Ito D, Honda T, Kubo K, Noda M, Nakajima K, Suzuki $N$ (2015) Characterization of the dipeptide repeat protein in the molecular pathogenesis of c9FTD/ALS. Hum Mol Genet 24:16301645. CrossRef Medline

Zhai J, Zhang L, Mojsilovic-Petrovic J, Jian X, Thomas J, Homma K, Schmitz A, Famulok M, Ichijo H, Argon Y, Randazzo PA, Kalb RG (2015) Inhibition of cytohesins protects against genetic models of motor neuron disease. J Neurosci 35:9088-9105. CrossRef Medline

Zhang K, Donnelly CJ, Haeusler AR, Grima JC, Machamer JB, Steinwald P, Daley EL, Miller SJ, Cunningham KM, Vidensky S, Gupta S, Thomas MA, Hong I, Chiu SL, Huganir RL, Ostrow LW, Matunis MJ, Wang J, Sattler R, Lloyd TE, et al. (2015) The C9ORF72 repeat expansion disrupts nucleocytoplasmic transport. Nature 525:56-61. CrossRef

Zhang YJ, Gendron TF, Grima JC, Sasaguri H, Jansen-West K, Xu YF, Katzman RB, Gass J, Murray ME, Shinohara M, Lin WL, Garrett A, Stankowski JN, Daughrity L, Tong J, Perkerson EA, Yue M, Chew J, Castanedes-Casey M, Kurti A, et al. (2016) C9ORF72 poly(GA) aggregates sequester and impair HR23 and nucleocytoplasmic transport proteins. Nat Neurosci 19:668-677. CrossRef Medline

Zhang YJ, Jansen-West K, Xu YF, Gendron TF, Bieniek KF, Lin WL, Sasaguri H, Caulfield T, Hubbard J, Daughrity L, Chew J, Belzil VV, Prudencio M, Stankowski JN, Castanedes-Casey M, Whitelaw E, Ash PE, DeTure M, Rademakers R, Boylan KB, et al. (2014) Aggregation-prone c9FTD/ALS poly(GA) RAN-translated proteins cause neurotoxicity by inducing ER stress. Acta Neuropathol 128: 505-524. CrossRef Medline

Zu T, Liu Y, Bañez-Coronel M, Reid T, Pletnikova O, Lewis J, Miller TM, Harms MB, Falchook AE, Subramony SH, Ostrow LW, Rothstein JD, Troncoso JC, Ranum LP (2013) RAN proteins and RNA foci from antisense transcripts in C9ORF72 ALS and frontotemporal dementia. Proc Natl Acad Sci USA 110:E4968-E4977. CrossRef 